\title{
COMPARATIVE ANALYSIS OF POTENTIAL EVAPOTRANSPIRATION CALCULATION METHODS WITH ERA-REANALYSIS CLIMATE MODELS' PROJECTIONS IN WESTERN ASIA, JORDAN
}

\author{
AL-Shibli, F. M. ${ }^{1 *}$ - OtTOM, M. A. ${ }^{2}-$ SAOUB, ${ }^{3}{ }^{3}-$ AL-Weshah, R. ${ }^{4}$ \\ ${ }^{1}$ Land, Water and environment Department, School of Agriculture, University of Jordan, 11942 \\ Amman, Jordan \\ ${ }^{2}$ Department of Information Systems, Yarmouk University, 21163 Irbid, Jordan \\ ${ }^{3}$ Department of Horticulture and Crop Science, School of Agriculture, University of Jordan, \\ 11942 Amman, Jordan \\ ${ }^{4}$ Department of Civil Engineering, School of Engineering, University of Jordan, 11942 Amman, \\ Jordan \\ "Corresponding author \\ e-mail:f.shibli@ju.edu.jo \\ (Received $21^{\text {st }}$ May 2021; accepted $3^{\text {rd }}$ Sep 2021)
}

\begin{abstract}
Evapotranspiration calculations are essential in quantifying available water, hydrological modelling, monitoring, and planning for drought occurrence and predicting its indices. Where observations are sparse and data quality is questionable; the need for simplified algorithm is urged. Thirteen models were used to calculate potential evapotranspiration $\left(\mathrm{ET}_{\mathrm{p}}\right)$ on daily and monthly time series meteorological data in Central Jordan-Amman City. Temperature-based, Class A-Pan evaporation (1970-2013), and solar radiation-based methods (1986-1999) were elaborated to estimate the reference ET. Evaluation and benchmarking were performed based on regression algorithm of linearity assumption against the climate models ETs projections of CMIP5-RCP 2.6, CLM-ERAi, Penman Monteith ERA Interim, and Priestley Taylor ERA-CLM. All methods to estimate ET ratify significant trends to the state of local climate. The analysis showed asymmetry between both CMIP5-RCP 2.6 and CLM-ERAi outputs and calculated ETs but inconsistent with Penman Monteith ERA Interim and Priestley Taylor ERA-CLM. Penman Monteith ERAInterim demonstrates the literature values that vary from 51 to $280 \mathrm{~mm} / \mathrm{month}$. Blaney Criddle and Hargreaves temperature and solar based formulas prototyped the potential evapotranspiration $\left(R^{2}=0.99-0.97\right)$ followed by Makkink and Jensen-Haise radiation-based formulas $\left(R^{2}=0.97-0.96\right)$. The remaining models need to be calibrated under the local conditions due to its limitation in the current constants.
\end{abstract}

Keywords: temperature-based, solar radiation-based ET, Pan evaporation, Amman - Jordan, CMIP5, ECMWF reanalysis

\section{Introduction}

Evapotranspiration is a main grouping of water balance since it includes the plant water uptake and evaporation and direct evaporation from soil. It can be defined as the maximum rate of evaporation and transpiration from fully covered crops with enough water applied to a field (Xu and Singh, 2001). Hence, many equations have developed over years to estimate the potential evapotranspiration based on the dependent variables that is mostly climatological quantities. Potential evapotranspiration is usually calculated as main input to hydrological models and simulated by climate models. Generally, 
temperature-based methods, solar radiation methods, class A-pan evaporation equation and aerodynamic and mass transfer-based methods are used.

The occurrence of climate extremes has increased as indices of climate change and variability which cause less available water to all sectors (Dingre and Gorantiwar, 2020). The most consumptive uses go to municipal and agricultural sectors (Al-Shibli et al., 2017) which urge to manage use in watering crops by unbiased evapotranspiration calculations. The importance of evapotranspiration calculations reflects the available water content after each precipitation event. The difference of rainfall and ET reflects the available water (Comair et al., 2012) diagnoses the drought, flood events and the trends of each rate. Particularly in limited water resources lands, ET calculations are essential for predicting drought and its indices.

Many studies use Penman method to calculate crop water requirement under semi-arid conditions (Dingre and Gorantiwar, 2020). Shahin (2007) has reported Jordan Rift evaporation by using three methods: Penman, Wartena and Neumann formulas. The yearly evaporation found by the three methods were; $2042 \mathrm{~mm}, 1685 \mathrm{~mm}, 1708 \mathrm{~mm}$, respectively (Wartena, 1959). Another study by Al-Mahamid (2005) demonstrated longterm seasonal ET values which vary from 65 to $170 \mathrm{~mm} / \mathrm{month}$ during winter months and vary from 129 to $250 \mathrm{~mm} / \mathrm{month}$ during summer over Amman-Zarqa Basin using Penman-Monteith method. According to the same study, ET reaches $640-680 \mathrm{~mm} / \mathrm{month}$ in some parts of the basin. Human induced-climate change and natural climate variability have contributed to drier dry seasons globally according to recent reconstruction studies (Padrón et al., 2020). The study reanalyzed the climate models to show the effects of climate change on the available water. It revealed the reason behind this dryness was the increasing of evapotranspiration inconsistently with the decreasing in precipitation over decades (Padrón et al., 2020). Regarding actual evapotranspiration, a new algorithm was developed by Guerschman et al. (2009) based on MODIS-Terra data images and calibrated using actual reading from seven stations across Australia then compared to average yearly difference between precipitation and runoff. The model showed promising approach since the actual ET values were fit with the runoff outputs especially in dry lands of study sites. The study elaborated a list of methods from each dependent variablebased equation excluding micrometeorological variables estimating the potential evapotranspiration.

Due to scarce data recordings and being as raw measures, it is required to specify the best method to calculate ET for hydro-meteorological modelling use and to quantify the available water remaining after each precipitation event. The study has investigated the trends of each based method with respect to climate models. The study compares the different potential evapotranspiration models in the middle of Jordan for the period from 1970 to 2013 using temperature-based, solar-based and pan evaporation methods. The comparison concluded the resemble trends in calculated methods' quality to represent the variations in weather and climates.

\section{Data and Methods}

\section{Study area}

Due to the scarce data, the study has focused on the most informative weather stations that have recorded most climate variables needed for the aim of the study sourced from Jordan Meteorological Department (JMD). The highest quality available observations are recorded in Amman Civil Airport Station. Missing data were filled from the neighbouring 
weather stations: Madaba, Salt and Queen Alia International Airport which distributed across the study area across the centre of Jordan-Amman as shown in (Fig. 1).

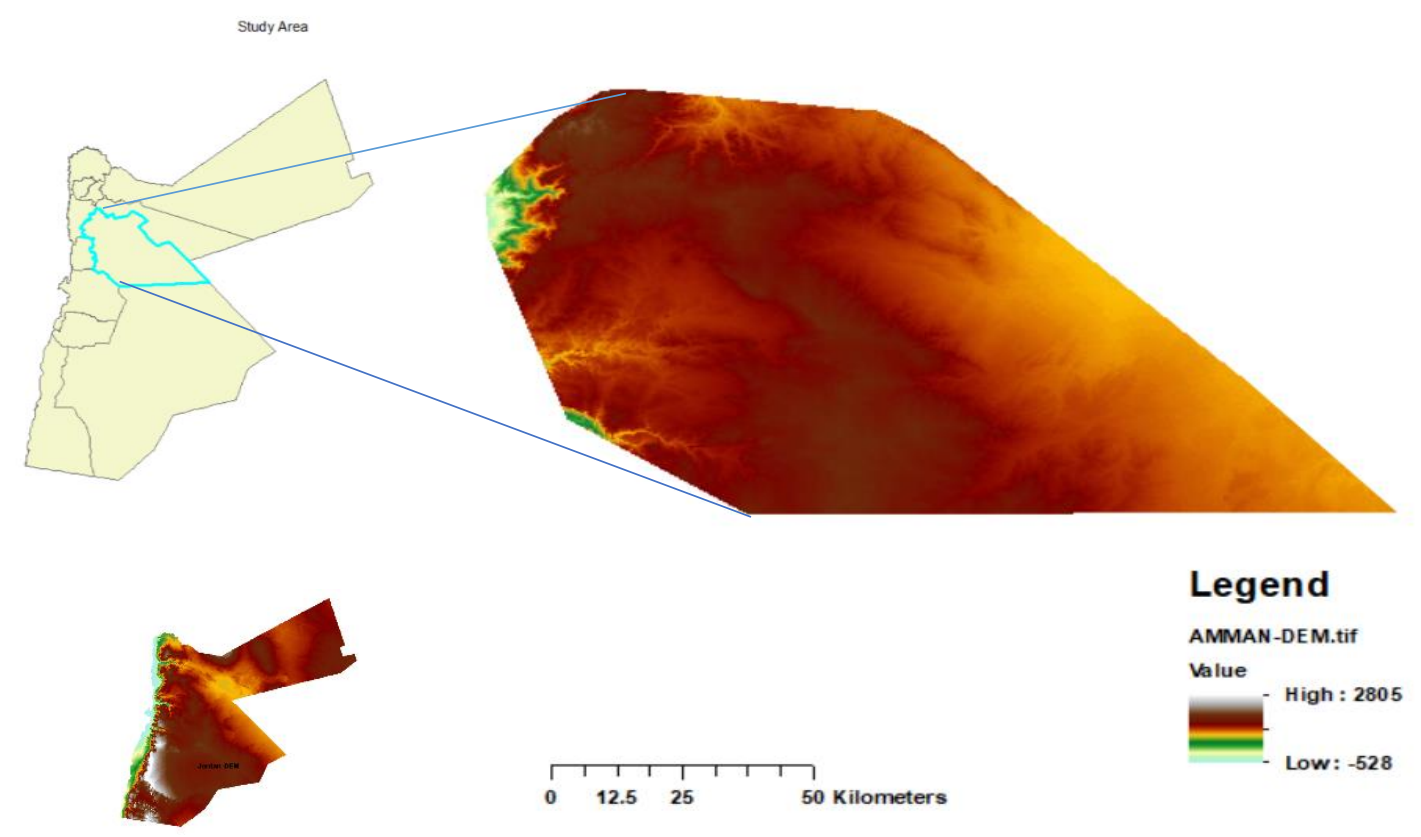

Figure 1. Study area in the center of Jordan. Digital Elevation Model (DEM) is retrieved from SRTM Data-CGIAR-CSI SRTM and modified for cropping purposes

\section{ET Calculations}

Thirteen formulas were used to calculate potential evapotranspiration on daily and monthly time series of meteorological data in Central Jordan-Amman. Temperature-, solar radiation-based methods and Class A-Pan evaporation were elaborated to estimate the potential evapotranspiration. Pre-whitening of observations datasets were avoided since the slope of trend is high and the sample size is large (Bayazit and Önöz, 2007).

Temperature-based and Pan methods calculated ET $\mathrm{p}$ from Jan 1979 to Dec 2013 since the available ERA reanalysis data is only during this period. The analysis emphasized on (Jan 1979-Jan 1999) time slice comparing with Penman Monteith-ERA Interim, and (Jan 1979-Dec 2013) time slice comparing with Priestley Taylor ERA-CLM.

Solar radiation-based methods calculated ET from April 1986 to Dec 1999 since the available radiation readings are only during this period. Therefore, the analysis emphasized on (April 1986-Jan 1999) time slice comparing with Penman Monteith-ERA Interim, and (April 1986-Dec 1999) time slice with Priestley Taylor ERA-CLM.

\section{Air Temperature-based Potential Evapotranspiration}

By availability of air maximum and minimum temperatures as daily recorded, temperatures-based equations can be used to calculate potential evapotranspiration. The following methods are discussed and used in this study.

- Hargreaves Method 
Hargreaves' first equation is written as in Eq. 1 (Hargreaves et al., 1985):

$$
E T \circ=0.0023 \operatorname{Ra} \sqrt{T D}\left(T_{a}+17.8\right)
$$

where; ET० is the potential Evapotranspiration in $\mathrm{mm} /$ day; $T D$ is the temperature difference $\left({ }^{\circ} \mathrm{C}\right) ; T_{a}$ is mean air temperature $\left({ }^{\circ} \mathrm{C}\right)$; and $R a$ is the water equivalent of extraterrestrial radiation ( $\mathrm{mm} /$ day). The equation has been modified many times (like: Allen et al., 1998; Trajkovic and Kolakovic, 2009) under different climate conditions where Talaee (2014) found that the best performance of the original Hargreaves method was in humid climate. A simple modification to Hargreaves equation in semi-arid and windy regions might require only precipitation daily measures (Talaee, 2014).

- Kharrufa Method

$$
E T \circ=0.34 p T a^{1.3}
$$

This method is used in arid and semi-arid climates by using another variable which is the mean daily percentage of annual daytime hours $(p)$ (Kharrufa, 1985); where ETo is Kharrufa potential evapotranspiration. A study for Xu and Singh (2001) found that Kharrufa Eq. 2 has seasonal bias especially in humid climate.

- Blaney-Criddle Method

Blaney and Criddle method (Blaney, 1952) and its modified formula below (Eq. 3) estimated the reference evapotranspiration $E T$ from a reference crop since it included the monthly consumptive use coefficient $k$ which depends on vegetation type, location and season (Blaney and Criddle, 1962). For the study, the study has estimated $E T / k$ avoiding crop specification.

$$
E T / k=p *(0.46 T a+8.13)
$$

where; $p$ is the percentage of total daytime hours for the period used out of total daytime hours of the year (Xu and Singh, 2001) and can be calculated using site information for latitude and Julian day (Rahimikhoob and Hosseinzadeh, 2014) and Ta as mentioned earlier. This method has been used as alternative equation to NOAA images for irrigated agriculture in a semi-arid region estimating ET०.

- Romanenko Method

Romanenko method is derived from the relation between monthly evapotranspiration and both variables mean air temperature $T a$ and mean monthly relative humidity $R h$ (Romanenko, 1961).

$$
E T=0.0018(25+T a)^{2}(100-R h)
$$

Romanenko original constants were recalibrated by many studies and concluded that the constant (0.002) might be used to estimate evapotranspiration in the Romanenko (Eq. 4) for many areas such as Sasireka and Xu studies (Xu and Singh, 2001; Sasireka et al., 2017) since the calculated ET by Romanenko was the most consistent results.

- Thornthwaite Method

It is an empirical method to estimate potential ET based on climate data such as radiation where this method works better in rainy seasons (Bautista et al., 2009). To 
calculate potential evapotranspiration $E T^{\prime}$ (Eq. 5), it requires (Thornthwaite, 1948) the average daily or monthly temperature $T a$ in ${ }^{\circ} \mathrm{C}$, the annual heat index $I$ which is the summation $E q$. 6 of 12 monthly indices $i$ which can be estimated again by $T a(E q .7)$, then to the power (a) of cubic phrase (written below in $E q .8$ ) of annual heat index $I$ and the constant 16 (Xu and Singh, 2001).

$$
\begin{gathered}
E T^{\prime}=16\left(\frac{10 T a}{I}\right)^{a} \\
I=\sum_{j=1}^{12} i j \\
i=\left(\frac{T a}{5}\right)^{1.51} \\
a=67.5 * 10^{-8} * I^{3}-77.1 * 10^{-6} * I^{2}+0.0179 * I+0.492
\end{gathered}
$$

Although using the original constants in Thornthwaite method could result large error as in Sasireka and Xu (Xu and Singh, 2001; Sasireka et al., 2017) used 25.69 instead of 16, it did not provide the best performance among temperature-based ET methods in semiarid climates (Akhavan et al., 2019). Since each month differs in average daylight hours $d$ and number of days in the month $N$, the adjusted evapotranspiration $E T$ as obtained in (Eq.9) is calculated according to site latitude and season.

$$
E T=E T^{\prime}\left(\frac{d}{12}\right) *\left(\frac{N}{30}\right)
$$

Despite Thornthwaite, as temperature decisive method, is suitable to assess drought (Ogunrinde et al., 2020), it worsens the results in arid regions (Zhou et al., 2020) due to rapid warming up recently (Duffy et al., 2021).

- Hamon Method

Hamon potential ET formula (Eq. 10) depends on daylight hours for a given day $D^{2}$, and basically on determining the saturated water vapor density $P t$ which calculated through exponential formula (Eq. 11) of air temperature Ta (Hamon, 1963).

$$
\begin{gathered}
E T=0.55 D^{2} * P t \\
P t=4.95 * e^{(0.062 T a)} / 100
\end{gathered}
$$

The use of original constants in the algorithm underestimated ET (Xu and Singh, 2001) whereas Zhou et al. (2020) found increasing dryness trend of PET in arid regions with least correlation but estimated severe drought in semi-arid and semi humid land.

\section{Solar radiation-based potential evapotranspiration}

- Jensen-Haise Method

Jensen-Haise estimated evapotranspiration in semi-arid and arid climate by recorded mean temperature $T a$ which required to calculate latent heat of vaporization $\lambda$ in $\mathrm{cal} / \mathrm{cm}^{3}$ as in Eq. 12 (Jensen and Haise, 1963). 


$$
\lambda(\mathrm{cal} / \mathrm{g})=595-(0.51 * \mathrm{Ta})
$$

The main algorithm (Eq. 13) uses daily total solar radiation $R s\left(\mathrm{cal} / \mathrm{cm}^{2}\right)$ that suitable for light to moderate windy Mediterranean climates where daily maximum temperature is not available (Samaras et al., 2014). Radiation based methods work better than the temperature-based methods especially for rainfall-runoff modelling studies (Bormann, 2011).

$$
E T=0.025(T a-(-3)) * R s / \lambda
$$

- Hargreaves method

The same inputs parameters that used in Jensen-Haise method are the same as in Hargreaves radiation formula shown in Eq. 14 (Hargreaves, 1994; Hargreaves and Allen, 2003) where $C t$ is empirical coefficient equals 17.8 (Hargreaves, 1994).

$$
E T=0.0135(T a+C t) R s / \lambda
$$

Since complex calibration of Hargreaves formula by using the real $R s$ and large number of variables led to less accuracy, the simplest (Allen, 1995) linear regression approach produced higher accuracy instead (Gomariz-Castillo et al., 2018).

- Abtew Method

This method ( $E q .16)$ is better used in warm humid to semi-humid climates with given solar radiation $R s$ in $\mathrm{MJ} / \mathrm{m}^{2} /$ day and $\lambda$ is in $\mathrm{MJ} / \mathrm{Kg}$ (Abtew, 1996; Xu, 2002) and can be calculated as in Eq. 16, further to some studies, Abtew formula performed better in semiarid area (Akhavan et al., 2019).

$$
\lambda=2.501-\left(2.361 * 10^{-3}\right) \mathrm{Ta}
$$

$K$ is the linear regression dimensionless coefficient equals 0.15 . In regard to winds, the conditions should not exceed moderate conditions (Samaras et al., 2014).

$$
E T=K * R s / \lambda
$$

\section{- Makkink Method}

The method (Makkink, 1957) performed better in cool humid and light-windy conditions (Samaras et al., 2014). The Eq. 17 requires (Hansen, 1984) the slope of saturation vapor pressure curve $\Delta$ by temperature showing in Eq. 18:

$$
\begin{gathered}
E T=0.61 \frac{\Delta}{\Delta+\gamma} \frac{R s}{58.5}-0.012 \\
\left.\Delta=33.8639\left[0.05904 *(0.00738 T a+0.8072)^{\wedge} 7\right)-0.0000342\right]
\end{gathered}
$$

$P$ is an atmospheric pressure in mbar at elevation above sea level in metres where assumed the average of Amman with maximum $1100 \mathrm{~m}$ and minimum $700 \mathrm{~m}$ elevation equals $900 \mathrm{~m}$, so $P$ is around 918.05 mbar calculated by $E q .19 . \gamma$ is the psychometric constant (in $\mathrm{mbar} /{ }^{\circ} \mathrm{C}$ ) can be calculated by $E q .20$ from the pressure and humidity 
dependent variable $C p$ which ranging from $\left(0.2397\right.$ to $\left.0.26 \mathrm{cal} / \mathrm{g} /{ }^{\circ} \mathrm{C}\right)$, and assumed here in the study as $0.242(\mathrm{Xu}, 2002)$.

$$
\begin{gathered}
\gamma=\frac{C p * P}{0.622 \lambda} \\
P=1013-0.1055 * E L
\end{gathered}
$$

The latent heat $\lambda$ is calculated by temperature ${ }^{\circ} \mathrm{C}$ as mentioned earlier, and then ET estimates by the Eq. 17. Sabziparvar and Tabari (2010) reported that Hargreaves method was the best performed radiation-based ET among other methods in arid and semi-arid climates.

- Doorenbos and Pruitt Method

Another recommended radiation method which used different climate parameteres is Doorenbos and Pruitt method Eq. 21 (Doorenbos, 1977). It required data of wind speed $U d(\mathrm{~m} / \mathrm{sec})$, relative humidity $R H(\%)$ to calculate adjustment coefficient $a$ as in $E q .22$ :

$$
\begin{gathered}
E T=a\left[\frac{\Delta}{\Delta+\gamma} R s\right]+b \\
a=1.066-0.13 * 10^{-2} R H+0.045 U d-0.20 * 10^{-3} R H \\
* U d-0.315 * 10^{-4} R H^{2}-0.11 * 10^{-2} U d^{2}
\end{gathered}
$$

In Doorenbos and Pruitt method, $R s$ is in mm/day, $b$ equals (-0.3) (Xu, 2002) and the remaining notations are all as same as in Makkink method. Fernández et al. (2010) found that Doorenbos and Pruitt calibrated radiation method was one of the most suitable approaches to estimate ET under standard conditions in Mediterranean climates.

\section{Pan Evaporation Method}

The evaporation $E p$ from a Pan with specific dimensions is an uncomplicated tool to estimate reference evapotranspiration (Eq. 23) under different climate conditions by determining pan coefficient $K p$.

$$
E T=E p * K p
$$

Different algorithms are used to calculate pan coefficient. In this study, two methods were applied to estimate the coefficient by given data (Tabari et al., 2013) of wind speed at $2.0 \mathrm{~m}$ height $U 2$, relative humidity, and the natural logarithm of fetch upwind distance $F$ (100 $\mathrm{m}$ acquiring for the maximum ET estimates) which are:

- Orange Kpan

Orang (1998) has concluded the linear logarithm (Eq. 24) of fetch upwind distance with wind speed and relative humidity.

$$
\begin{aligned}
\text { Kpan }= & 0.51206-(0.000321 * U 2)+(0.002889 * R H) \\
& +(0.03188 * \ln (F))-(0.000107 * R H * \ln (F))
\end{aligned}
$$


- Allen Kpan

Allen et al. (1998) has computed the coefficient (Eq. 25) by the quadratic natural log of $F$ comparing the evaporation from the pan with values of reference ET from different crops under different growth stages.

$$
\begin{gathered}
\text { Kpan }=0.108-(0.0286 * U 2)+0.0422 * \ln (F)+0.1434 * \\
\ln (R H)-0.000631 *[\ln (F)]^{2} * \ln (R H)
\end{gathered}
$$

\section{Climate models}

There are wide range of climate simulations that illustrate the history and future climate using wide range of systematic algorithms and theories called climate models projections. Each model represents range of possible future scenarios of climate parameters and range of carbon emission scenarios (RCPs) based on historical baselines vary with time and place. Coupled Model Intercomparison Project Phase 5 (CMIP5) is an ensemble representing of 34 models, which predict $1.8 \pm 0.6{ }^{\circ} \mathrm{C}$ the increase of transient climate response in temperature (Flato et al., 2013; Nahar et al., 2020; Dosio et al., 2021). If the carbon emission concentration releases $2.2 \mathrm{watt} / \mathrm{m}^{2}$ of effective radiative forcing (this scenario which represents RCP 2.6 (shortened to RCP26)), the peak emission years will be around (2010-2020) and the increasing of global surface temperature will be $0.4-1.6 \pm 0.4^{\circ} \mathrm{C}$ to $0.3-1.7 \pm 0.3^{\circ} \mathrm{C}$ during the period (2046-2065) and (2081-2100) respectively (Flato et al., 2013; Stocker et al., 2013). The projections outputs of CMIP5RCP26 are evaluated in this study. All climate models datasets retrieved from (http://climexp.knmi.nl), according to the instructions of Trouet (Trouet and Van Oldenborgh, 2013). The climate models' datasets details are illustrated in Table 1.

Table 1. List of climate models conducted in the study, its grid box coordinates, and the data

\begin{tabular}{|c|c|c|c|c|c|c|c|}
\hline \multirow[b]{2}{*}{ Model experiment } & \multirow{2}{*}{$\begin{array}{c}\text { Horizontal } \\
\text { Resolution } \\
\text { (Long x Lat) }\end{array}$} & \multicolumn{4}{|c|}{ Interpolating points } & \multicolumn{2}{|c|}{ Time scale } \\
\hline & & \multicolumn{2}{|c|}{$\begin{array}{c}\text { Long extent in } \\
\text { degrees }(E)\end{array}$} & \multicolumn{2}{|c|}{$\begin{array}{l}\text { Lat extent in } \\
\text { degrees }(N)\end{array}$} & Start & End \\
\hline $\begin{array}{l}\text { multi-model mean } \\
\text { CMIP5 ET - rcp26 }\end{array}$ & $2.5^{\circ} \times 2.5^{\circ}$ & 33.750 & 36.250 & 31.250 & 33.750 & Jan 1970 & Dec 2013 \\
\hline Mean ET-CLM-ERAi & $1.0^{\circ} \times 0.9^{\circ}$ & 35.000 & 36.000 & 31.571 & 32.513 & Jan 1979 & Dec 2013 \\
\hline $\begin{array}{c}\text { Penman Monteith } \mathrm{ET}_{\mathrm{p}} \text { - } \\
\text { ERA-Interim }\end{array}$ & $0.7^{\circ} \times 0.7^{\circ}$ & 35.859 & 36.563 & 32.632 & 31.930 & Jan 1979 & Jan 1999 \\
\hline $\begin{array}{l}\text { Priestley Taylor } \text { ET }_{\mathrm{p}^{-}} \\
\text {ERA-CLM }\end{array}$ & $1.25^{\circ} \times 0.9^{\circ}$ & 35.625 & 36.875 & 31.099 & 32.042 & Jan 1979 & Dec 2013 \\
\hline Weather Station & - & 35.9 & $5(\mathrm{X})$ & 31.968 & $56(\mathrm{Y})$ & Jan 1970 & Dec 2013 \\
\hline
\end{tabular}
time series period used in the analysis

Another product from the European Centre for Medium Range Weather Forecast (ECMWF) Interim Reanalysis (ERA-Interim) data are used in this study. The product improved model physics of climate parameters including evaporation. Also, it varied satellite radiance data with faster radiative transfer model particularly a new humidity analysis and better representation of atmospheric physics (de Lima and Alcântara, 2019). The reanalysis of Interim gridded datasets quality were validated to observations and fitted to systematic hydrologic measures globally (Uppala et al., 2008). Most studies have 
analyzed one variable on specific region to validate the ERA datasets with observations such as Wang et al. (2015) and Simmons et al. (2004) and concluded the ERA capability to perform better in the region of interest despite some errors that may be adjusted using best algorithms (de Lima and Alcântara, 2019). Hence it provides robust improvement in temporal consistency datasets and more sensible representation of observations (Dee et al., 2011), this study has selected the ERA-Interim as benchmark to validate the calculated reference evapotranspiration. The study has elaborated the monthly frequency ERAinterim where the horizontal grid spacing is around $83 \mathrm{~km}\left(0.75^{\circ} \times 0.75^{\circ}\right)$ and the grid boundaries have interpolated points.

Penman Monteith $\mathrm{ET}_{\mathrm{p}}$ - ERA-Interim input data obtained from the Pre-Processor for LISFLOOD model estimated by Penman-Monteith combined approach (Monteith, 1965) using Angot radiation to calculate net-longwave radiation (Burek et al., 2013). PenmanMonteith equation is widely used in literature, and shortly, it calculates land surface evaporation by combining the sensible heat and latent heat with energy balance giving the Eq. 26.

$$
\lambda E T=\frac{\varepsilon A+\left(\frac{\rho C p}{\gamma}\right) D a G a}{\varepsilon+1+\frac{G a}{G s}}
$$

where $\lambda$ is measured in $(\mathrm{MJ} / \mathrm{kg})$, the $\gamma$ psychometric constant is measured here in $\left(\mathrm{kPa} /{ }^{\circ} \mathrm{C}\right), \varepsilon$ is $(s / \gamma)$, the available energy $A$ estimated from net radiation and $G$ soil heat flux density $\left(\mathrm{MJ} / \mathrm{m}^{2} / \mathrm{d}\right), G a$ and $G s$ are aerodynamic and surface conductances $(\mathrm{m} / \mathrm{sec})$, $D a$ is vapor pressure deficit of air $(\mathrm{kPa})$, air density $\rho$ in $\mathrm{g} / \mathrm{m}^{3}$, and $C p$ is the specific heat of air at constant pressure $\left(\mathrm{J} / \mathrm{g} /{ }^{\circ} \mathrm{C}\right)$. Penman-Monteith model proved its reliability to estimate, at catchmnet scale, the short-term and long-term evaporation (Zhang et al., 2008).

Priestley Taylor ETp-ERA-CLM (Szilagyi et al., 2014; Philip et al., 2020) that obtained from the ERA-Interim reanalysis data calculates potential ET using Priestley Taylor equation (Priestley and Taylor, 1972) that depend on ECMWF heat fluxes. All variables in Priestly-Taylor Equation have the same meanings and units as those in Penman-Monteith method. Priestly Taylor used a calibration constant $\alpha=1.26 ; \Delta$ is the slope of saturation vapor pressure-temperature curve $\left(\mathrm{kPa} /{ }^{\circ} \mathrm{C}\right) ; R n$ the net radiation in $\left(\mathrm{MJ} / \mathrm{m}^{2} /\right.$ day) which can be derived from solar radiation and extraterrestrial radiation; and $G$ is the heat flux density to the ground (MJ/m²/day), see Eq. 27 (Lu et al., 2005).

$$
\lambda E T=\alpha \frac{\Delta}{\Delta+\gamma}(R n-G)
$$

ERA-Interim assimilation methodology, model, and observations are detailed in Dee's research (Dee et al., 2011) and evaluated by Kunz's article (Kunz et al., 2014) using high quality airborne water vapor measurements dataset rather than the satellite data that unable to accurately track down gas distributions.

\section{Models evaluation}

In order to choose the best fit calculated $\mathrm{ET}_{\mathrm{p}}$ among all based meteorological variables and equations, the study used regression model evaluation represented in Eq. 28 to describe the relationship between the benchmark climate models ET projections for the 
baseline period and the different calculation methods. The analysis conducted RStudio coding to summarize linear regression test and graphing.

$$
\gamma=\beta 1+\beta 2 x+\varepsilon
$$

where; $\beta_{1}$ is the intercept, $\beta_{2}$ is the slope and $\varepsilon$ is the error term. The metrics used for model's evaluation are in the following Eqs. 29 to 34 (Ahmad, 2013; Wickham and Grolemund, 2016):

$$
\begin{gathered}
t-\text { Statistic }=\frac{\beta \text {-coefficients }}{\text { Std.Error }} \\
\text { Multiple R-squared }=R^{2}=1-\frac{\sum_{i}^{n}(\mathrm{y} i-\hat{\mathrm{y}} i)^{2}}{\sum_{i}^{n}(\mathrm{y} i-\overline{\mathrm{y}} i)^{2}} \\
\text { Adjusted R-squared }=R_{a d j}^{2}=1-\left(\frac{\left(1-R^{2}\right)(n-1)}{n-q}\right) \\
\text { Std.Error }=\sqrt{M S E}=\sqrt{\frac{S S E}{n-q}} \\
F-S t a t i s t i c=\frac{M S R}{M S E} \\
M S R=\frac{\sum_{i}^{n}(\hat{\mathrm{y}}-\overline{\mathrm{y}})^{2}}{q-1}
\end{gathered}
$$

where; $\hat{y} i$ is the fitted value for observations, $\bar{y} i$ is the mean of $\mathrm{y}, n$ is the number of observations, $q$ is the number of coefficients in the model, $S S E$ is the summation of squared errors, $M S E$ is a mean squared error, and $M S R$ is the mean squared regression.

\section{Results}

Running RStudio for evaluating the model between calculated ETs and climate models projections ETs, illustrated through plots and descriptive statics. Here the study divided the analysis into daily and monthly statistics. The resemblance methods were analysed with regression algorithm to measure the quality of the evapotranspiration methods as surrogates of modelled ETs. It evaluates the fitted model in order to be elaborated later in future water availability studies.

The results showed how changes in climatic conditions will change evapotranspiration estimates. The ET trends showed the sensitivity of evapotranspiration to temperature and radiation through the year. Through the temporal comparison with long-term $\mathrm{ET}_{\mathrm{p}}$ values, CMIP5-RCP26 and CLM-ERAi showed a performance in the projections that might change as a function of the state of climate. Fig. 2 illustrated the trends of ET that are lower in winter months and higher during warm month matching with Penman MonteithERA-Interim and Priestley Taylor-ERA-CLM ET ${ }_{\mathrm{p}}$, whereas, CMIP5-RCP26 and CLMERAi ETs are the opposite of such trends. Therefore, CMIP5-RCP26 and CLM-ERAi are excluded from models evaluations analysis. 


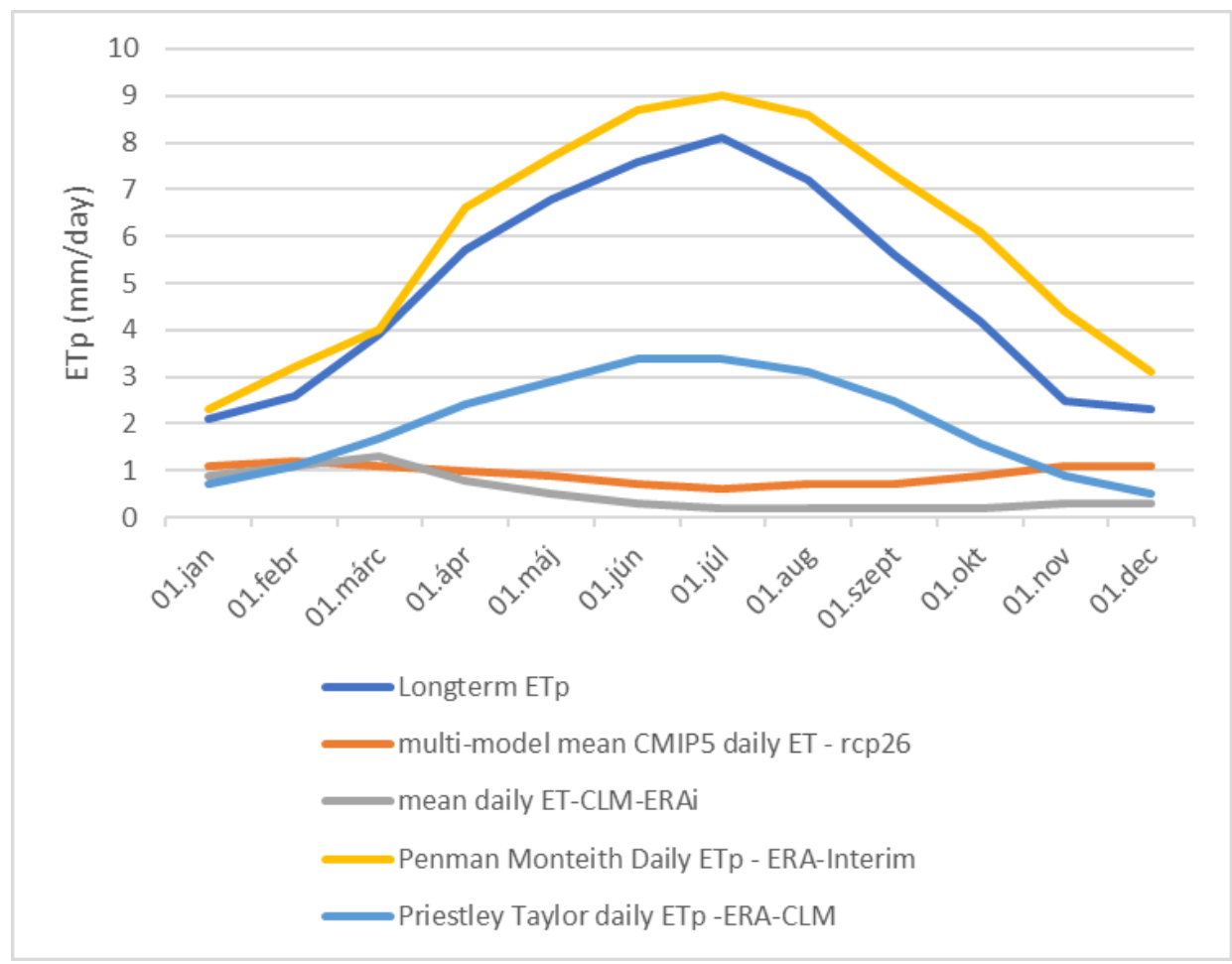

Figure 2. Temporal change of ET through climate models projections comparing with longterm values in Amman

\section{Regression analysis}

\section{Calculated temperature-based daily ET methods}

The aggregate plots (Fig. 3) instantly show the relationship of all variables; the calculated temp-based daily ET methods, Hargreaves, Karrufa and Blaney-Criddle equations, are correlated positively as strongly linear, wherein the RCP26-CMIP5 mean daily evaporation is negatively correlated to all calculated temperature-based daily ET methods. Mean daily ET-CLM-ERAi is positively correlated with CMIP5 and vector negatively with temperature-based daily $\mathrm{ET}_{\mathrm{p}}$ methods. By looking merely at the scatterplots, Penman Monteith- ERA-Interim daily ET $\mathrm{p}_{\mathrm{p}}$ and Priestley Taylor-ERA-CLM daily $\mathrm{ET}_{\mathrm{p}}$ are in positive relation with temperature-based daily $\mathrm{ET}_{\mathrm{p}}$ methods but stronger linear relation to Penman ET . On the contrary, Penman $\mathrm{ET}_{\mathrm{p}}$ is moderately inverse proportional to mean monthly CLM-ERAi and ensemble RCP26-CMIP5 evaporation estimations whereas the latter is clustering negative correlation with Priestly daily $\mathrm{ET}_{\mathrm{p}}$.

The descriptive analysis (Table 2) detected statistically the variant range of potential evapotranspiration calculating by observations of daily climatic data. Hargreaves method ranged from $1.2 \mathrm{~mm}$ to $6.6 \mathrm{~mm}$ maximum while Blaney-Criddle from $2.4 \mathrm{~mm}$ to $6.7 \mathrm{~mm}$. Karrufa exceeded the maximum values over all methods as it reached $8.3 \mathrm{~mm}$ during the 528 months. Penman Monteith is more closely to Blaney-Criddle values. The daily tempbased $\mathrm{ET}_{\mathrm{p}}$ means and $3^{\text {rd }}$ quartiles are nearly the same, in comparison to the approximate $1^{\text {st }}$ quartile Penman and maximum Priestly values, further to the $5.7 \mathrm{~mm} 3^{\text {rd }}$ quartiles of temp-based ET 's equal the mean of Penman ET $_{\mathrm{p}}$ through the study period. 


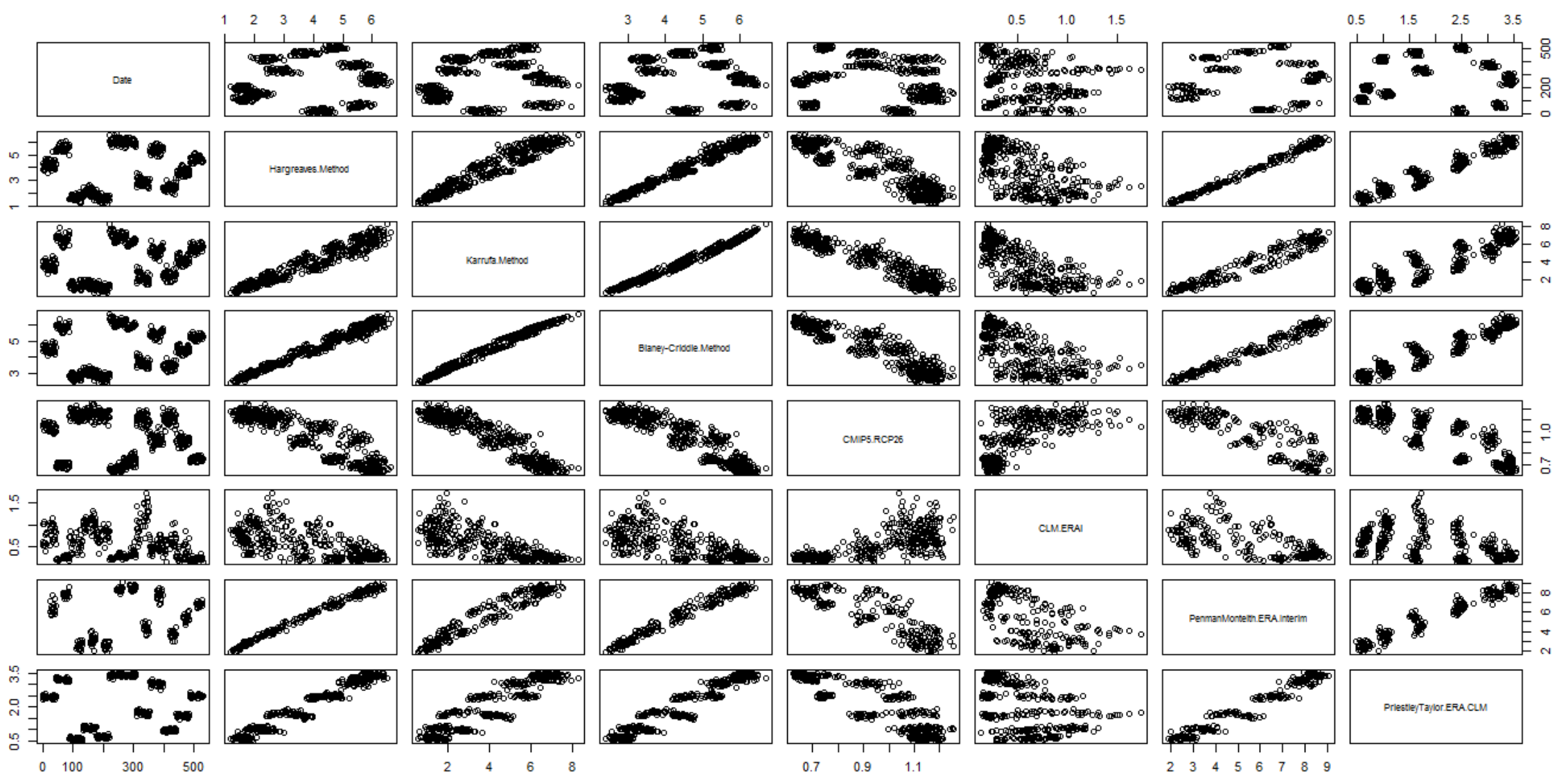

Figure 3. Plotting Hargreaves, Karrufa and Blaney-Criddle daily ETs against RCP26-CMIP5, ET-CLM-ERAi, Penman Monteith-ERA-Interim daily $E T_{p}$ and Priestley Taylor-ERA-CLM daily ET, where ETs in $\mathrm{mm}$ 
Table 2. Descriptive stats: Temperature-based Daily ET $T_{p}$ methods covering 528 months of observations in comparison to Climate Models and projections (ET in $\mathrm{mm}$ )

\begin{tabular}{|c|c|c|c|c|c|c|c|}
\hline Method & $\begin{array}{l}\text { Hargreaves } \\
\text { Method }\end{array}$ & $\begin{array}{l}\text { Karrufa } \\
\text { Method }\end{array}$ & $\begin{array}{l}\text { Blaney- } \\
\text { Criddle } \\
\text { Method }\end{array}$ & $\begin{array}{l}\text { CMIP5- } \\
\text { RCP26 }\end{array}$ & $\begin{array}{l}\text { CLM- } \\
\text { ERAi }\end{array}$ & \begin{tabular}{|c|} 
Penman \\
Monteith ERA- \\
Interim \\
\end{tabular} & $\begin{array}{c}\text { Priestley } \\
\text { Taylor ERA- } \\
\text { CLM } \\
\end{array}$ \\
\hline Min. & 1.186 & 0.5661 & 2.415 & 0.6257 & 0.1406 & 1.926 & 0.4863 \\
\hline 1st Qu. & 2.257 & 1.8635 & 3.237 & 0.7373 & 0.2601 & 3.483 & 1.0231 \\
\hline Median & 3.915 & 3.9396 & 4.448 & 0.9881 & 0.489 & 5.782 & 2.1195 \\
\hline Mean & 3.858 & 3.9502 & 4.437 & 0.9467 & 0.554 & 5.6 & 2.0525 \\
\hline 3rd Qu. & 5.499 & 5.9028 & 5.598 & 1.1234 & 0.7823 & 7.812 & 3.1381 \\
\hline Max. & 6.614 & 8.2653 & 6.685 & 1.2532 & 1.7394 & 9.39 & 3.5407 \\
\hline
\end{tabular}

\section{Calculated temperature-based monthly ET methods}

The analysis in Table 3 detected statistically the variant range of potential evapotranspiration calculating by observations of monthly climatic data. Romanenko method ranged from $25.3 \mathrm{~mm}$ to $290.5 \mathrm{~mm}$ maximum while Thornthwaite from $2.09 \mathrm{~mm}$ to $150 \mathrm{~mm}$. Hamon exceeded the maximum values over all methods as it reached $540 \mathrm{~mm}$ during the study period. Penman Monteith is more closely to Romanenko values whereas Priestly Taylor ERA-CLM is approximate to Thornthwaite in third quartile.

Table 3. Descriptive stats: Temperature-based monthly ET $T_{p}$ methods covering 528 months of observations in comparison to Climate Models and projections (ET in mm)

\begin{tabular}{c|c|c|c|c|c|c|c}
\hline $\begin{array}{c}\text { Method } \\
\text { Metrics }\end{array}$ & $\begin{array}{c}\text { Romanenko } \\
\text { Method }\end{array}$ & $\begin{array}{c}\text { Thornthwaite } \\
\text { Method }\end{array}$ & $\begin{array}{c}\text { Hamon } \\
\text { Method }\end{array}$ & $\begin{array}{c}\text { CMIP5. } \\
\text { RCP26 }\end{array}$ & $\begin{array}{c}\text { CLM. } \\
\text { ERAi }\end{array}$ & $\begin{array}{c}\text { PenmanMonteith } \\
\text {-ERA.Interim }\end{array}$ & $\begin{array}{c}\text { PriestleyTaylor- } \\
\text { ERA.CLM }\end{array}$ \\
\hline Min. & 25.27 & 2.086 & 6.954 & 19.40 & 4.219 & 51.4 & 15.07 \\
1st Qu & 76.71 & 16.132 & 66.283 & 22.19 & 8.028 & 101.3 & 29.58 \\
Median & 144.85 & 52.269 & 165.589 & 30.00 & 14.884 & 177.3 & 64.54 \\
Mean & 143.14 & 56.891 & 204.539 & 28.76 & 16.761 & 170.6 & 62.59 \\
3rd Qu & 204.04 & 94.651 & 328.721 & 33.94 & 23.824 & 242.2 & 97.28 \\
Max. & 290.54 & 150.139 & 539.844 & 38.10 & 53.921 & 280.2 & 109.76 \\
NA's & Nil & Nil & Nil & Nil & 108 & 287 & 108 \\
\hline
\end{tabular}

The plots in Fig. 4 instantly show the relationship of all variables; the calculated ET methods are correlated positively wherein the RCP26-CMIP5 mean monthly evaporation is negatively correlated to all calculated temperature-based monthly ET methods. Mean monthly ET-CLM-ERAi is positively correlated with CMIP5 and vector negatively with temperature-based monthly $\mathrm{ET}_{\mathrm{p}}$ methods. By looking merely at the scatterplots, Penman Monteith- ERA-Interim monthly sum of ET p $_{\mathrm{p}}$ and Priestley Taylor-ERA-CLM monthly $\mathrm{ET}_{\mathrm{p}}$ are in positive relation with temperature-based monthly $\mathrm{ET}_{\mathrm{p}}$ methods, on the contrary, both are inversely proportional to Mean monthly CLM-ERAi and ensemble RCP26-CMIP5 evaporation estimations. 


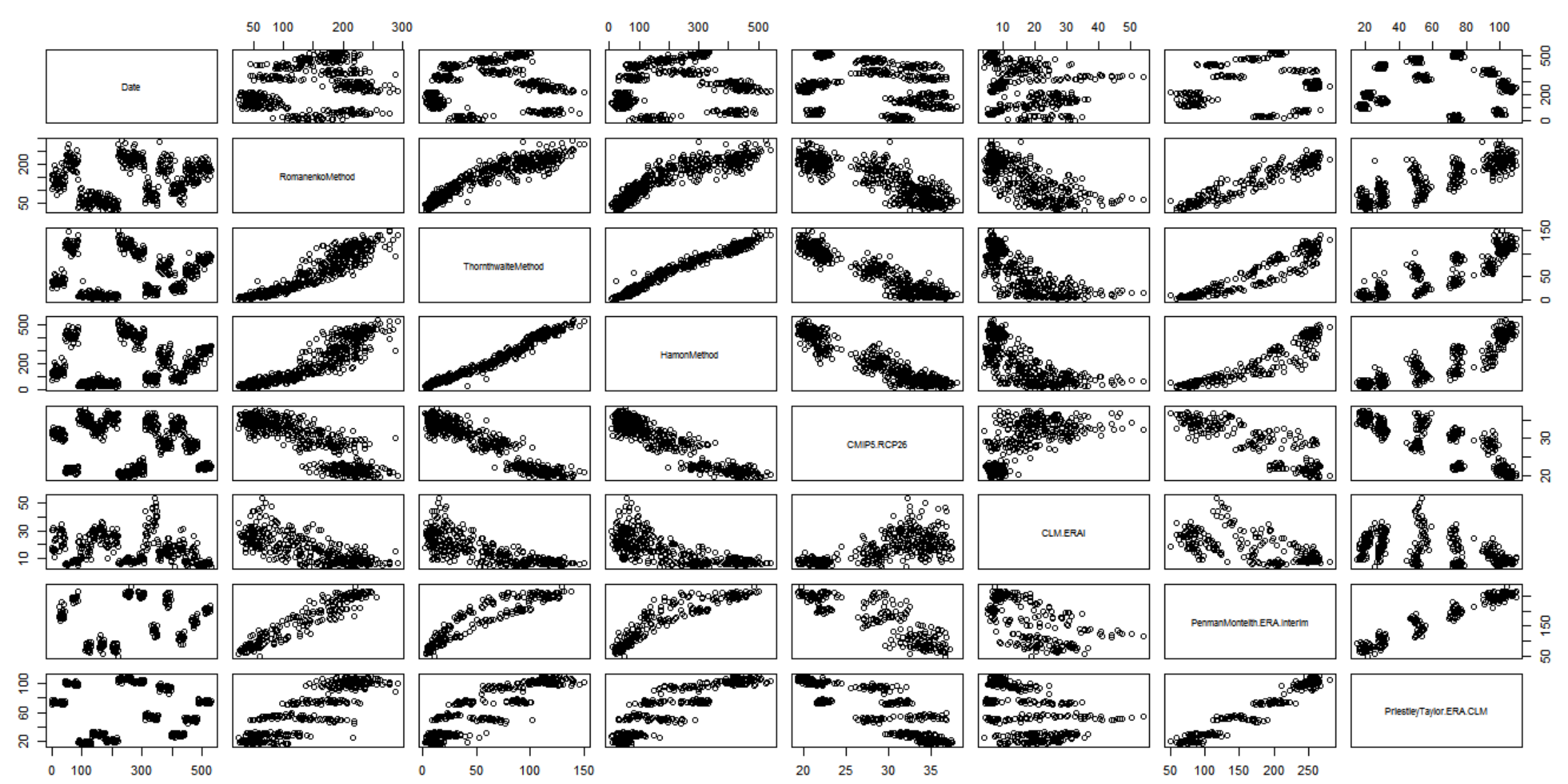

Figure 4. Plotting Romanenko, Thornthwaite and Hamon monthly ETs against RCP26-CMIP5, ET-CLM-ERAi, Penman Monteith-ERA-Interim monthly ET $T_{p}$ and Priestley Taylor-ERA-CLM monthly ET, where ETs in $\mathrm{mm}$ 


\section{Class A-Pan method}

The plots instantly showed in Fig. 5 the strong positive linear correlation between both Class A-Pan methods of, Orange Kp and Allen Kp, and moderate correlation with Penman Monteith- ERA-Interim monthly sum of $\mathrm{ET}_{\mathrm{p}}$ detecting continuous dots. On the other hand, Priestley Taylor-ERA-CLM monthly ET $_{\mathrm{p}}$ correlated positively in clusters (closed sets of points) within wider range versus Orange $\mathrm{Kp}$ and Allen Kp ET values. On the contrary, Priestley Taylor-ERA-CLM monthly ETp scatter plot formed distinct clusters but narrow range against Penman Monteith- ERA-Interim ETp.

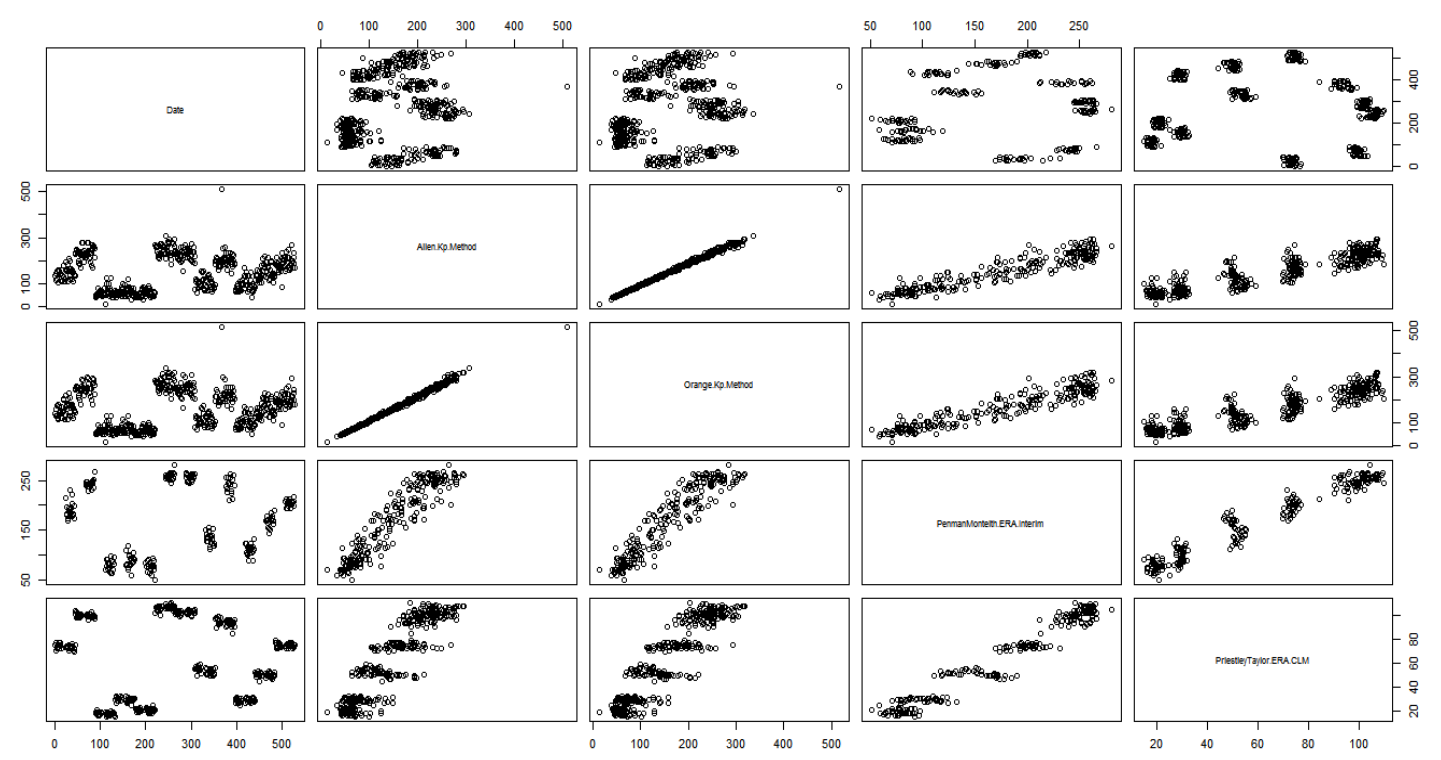

Figure 5. Correlation between Class A-Pan methods of, Orange Kp and Allen Kp with Penman Monteith-ERA-Interim monthly ET $T_{p}$ and Priestley Taylor-ERA-CLM monthly ET

Evapotranspiration calculated values by using Orange Kp and Allen Kp resembled to Penman Monteith- ERA-Interim ET $\mathrm{p}_{\mathrm{p}}$ in median, mean, $1^{\text {st }}$ and $3^{\text {rd }}$ quartiles; whereas Priestley Taylor-ERA-CLM monthly $\mathrm{ET}_{\mathrm{p}}$ minimum value has a unique approximate to Orange Kp and Allen Kp evapotranspiration, stats are detailed in Table 4.

Table 4. Descriptive stats: Class A-Pan monthly ET methods covering 528 months of observations in comparison with ERA projections (ET in $\mathrm{mm}$ )

\begin{tabular}{c|c|c|c|c}
\hline Method & Orange Kp Method & Allen Kp Method & $\begin{array}{c}\text { Penman Monteith- } \\
\text { Monthly ERA Interim }\end{array}$ & $\begin{array}{c}\text { Priestley Taylor- } \\
\text { Monthly ERA.CLM }\end{array}$ \\
\hline Min. & 13.64 & 14.99 & 51.4 & 15.07 \\
1st Qu & 78.02 & 83.94 & 101.3 & 29.58 \\
Median & 145.87 & 154.74 & 177.3 & 64.54 \\
Mean & 148.41 & 158.16 & 170.6 & 62.59 \\
3rd Qu & 211.4 & 225.83 & 242.2 & 97.28 \\
Max. & 507.78 & 515.37 & 280.2 & 109.76 \\
NA's & Nil & Nil & 287 & 108 \\
\hline
\end{tabular}




\section{Solar-based monthly evapotranspiration}

The plots (in Fig. 6a) instantly showed the roughly to moderate positive linear correlation between Doorenbos \& Pruitt Method and Penman-Monteith-Monthly SumERA-Interim. A positive clustering with Priestley Taylor Monthly ET p $^{-E R A-C L M ~ i s ~}$ detecting ascending dots and smoothing fit-line curve (see the plots in Fig. 6b). On the contrary, Priestley Taylor-ERA-CLM monthly $\mathrm{ET}_{\mathrm{p}}$ scatter plot formed distinct clusters but narrow range against Penman Monteith- ERA-Interim ET . $_{\text {. }}$

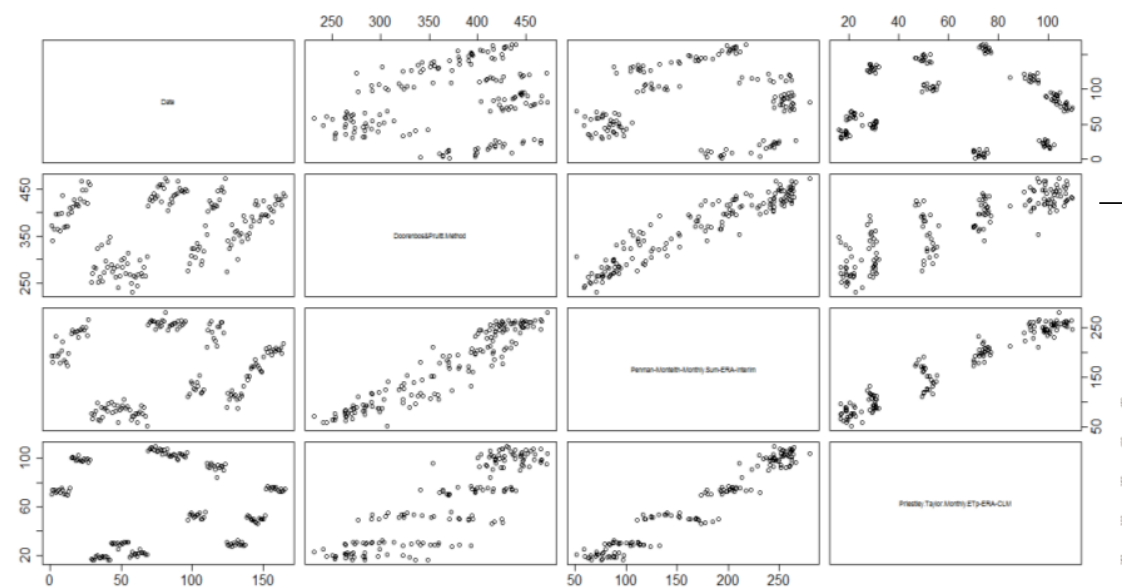

(a)

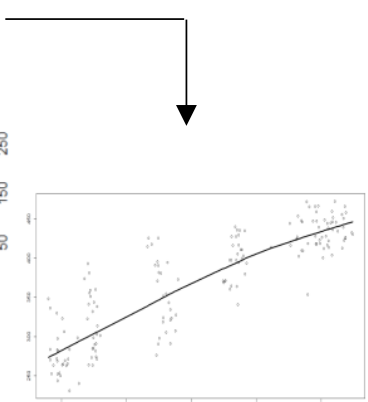

(b)

Figure 6. (a) Doorenbos \& Pruitt Method against Penman-Monteith-Monthly Sum-ERAInterim; and (b) ascending fit-line with Priestley Taylor Monthly ET $T_{p}$ ERA-CLM

Despite the correlation between Doorenbos \& Pruitt ET $\mathrm{p}$ solar-based method and the climate projection month-long methods, the values are varied. The maximum values of Priestly $E_{p}$ is approximate to $1^{\text {st }}$ quartile Penman $E_{p}$ whereas the maximum Penman $\mathrm{ET}_{\mathrm{p}}$ is about the $1^{\text {st }}$ quartile of Doorenbos $\mathrm{ET}_{\mathrm{p}}$, the latter exceeded $470.0 \mathrm{~mm}$ monthly evapotranspiration (see Table 5).

Table 5. Descriptive stats: Solar-Based Monthly Doorenbos \& Pruitt ET $T_{p}$ Method covering 165 months of observations in comparison to Penman-Monteith ERA-Interim and PriestleyTaylor ERA-CLM monthly sum projections (ET in $\mathrm{mm}$ )

\begin{tabular}{c|c|c|c}
\hline Method & Doorenbos \&Pruitt Method & $\begin{array}{c}\text { Penman-Monteith- } \\
\text { Monthly Sum-ERA- } \\
\text { Interim }\end{array}$ & $\begin{array}{c}\text { Priestley Taylor Monthly ET } \mathrm{p}_{\mathrm{p}} \\
\text { ERA-CLM }\end{array}$ \\
\hline Min. & 230.8 & 51.4 & 15.96 \\
1 st Qu & 306.1 & 101.3 & 29.8 \\
Median & 390.8 & 179.6 & 69.99 \\
Mean & 369.7 & 171.6 & 62.93 \\
3rd Qu & 426.2 & 244.4 & 96.35 \\
Max. & 472.5 & 280.2 & 109.76 \\
NA's & Nil & 11 & Nil \\
\hline
\end{tabular}




\section{Solar-based daily $E T_{p}$ methods}

Looking at the plots as representing in Fig. 7, simply it showed the strong and linear pattern between Jensen-Haise, Hargreaves and Makkink evapotranspiration values over 165 months. Abtew ET values were interpreted as positive strong correlation against Makkink, and Hargreaves methods but moderately linear. Wherein versus Jensen-Haise evapotranspiration values, Abtew ETs associate strongly in positive non-linear over-plotting data. While CLM-ERAi and ensemble RCP26-CMIP5 evaporation estimations have negative relationship with calculated ET methods, it shows clusters vs RCP26-CMIP5 and outliers vs CLM.ERAi at the end of the study period.

Solar-based $\mathrm{ET}_{\mathrm{p}}$ values correlated moderately with Penman Monteith- ERA-Interim monthly sum of $\mathrm{ET}_{\mathrm{p}}$ detecting continuous dots. On the other hand, Priestley Taylor-ERACLM monthly $\mathrm{ET}_{\mathrm{p}}$ correlated positively in clusters (closed sets of points) within wider range versus Orange $\mathrm{Kp}$ and Allen Kp ET values. On the contrary, Priestley Taylor-ERA-CLM monthly $\mathrm{ET}_{\mathrm{p}}$ scatter plot formed distinct clusters but narrow range against Penman Monteith- ERA-Interim ET $_{\mathrm{p}}$. No relations were shown between CLM.ERAi and both Penman Monteith- ERA-Interim and Priestley Taylor-ERA-CLM monthly ET $_{p}$ estimations. Clusters with gaps were vector the negative correlation between CMIP5 and both Penman Monteith- ERA-Interim and Priestley Taylor-ERA-CLM monthly ET $_{\mathrm{p}}$ values.

The metrics in descriptive stat in Table 6 showed the narrow range of daily evapotranspiration values between calculated solar-based equations and climate projections. Priestley-Taylor ERA-CLM projections are more similar to Jensen-Haise Method and Hargreaves Method while Abtew Method is more analogous to Penman-Monteith-ERAInterim. One of the calculated methods, Makkink equation, ranged out of the distributions of other variables from 4.6 to $24.0 \mathrm{~mm}$ per day.

\section{Models' evaluation}

The previous scatter plots show the linear regression between variables varied from strong to weak relation and meet the assumption for performing the regression analysis to linearity.

\section{Calculated temperature-based Methods}

The residuals between Hargreaves, Karrufa and Blaney Criddle equations with both Penman Monteith and Priestley Taylor daily ET are mostly approximate but not completely exact. The coefficients of linear relations showed, for example, the value of Y intercept 0.533 and the estimated effect of Penman relation on Hargreaves ET (1.32). All calculated methods meet the null hypothesis (here it is less than $2 \mathrm{e}-16$, or almost zero and indicate that the model fits the data well).

From Table 7 results, we can say that there is strong significant positive relationship between daily Penman Monteith and daily Hargreaves equation $\left(\mathrm{R}^{2}=0.99\right)$ and with BlaneyCriddle equation $\left(\mathrm{R}^{2}=0.97\right)$ followed by Priestly Taylor and Hargreaves $\left(\mathrm{R}^{2}=0.96\right)$ and with Blaney Criddle $\left(\mathrm{R}^{2}=0.93\right)$. Furthermore, $\mathrm{p}$-Value consider a linear model to be statistically significance level when both the model $\mathrm{p}$-Value and of the variables less than 0.05 which all met here in the summary statistics of daily calculated Temp-based methods. Karrufa equation performed better with Penman Monteith $\left(\mathrm{R}^{2}=0.92\right)$ rather than with Priestley Taylor $\left(\mathrm{R}^{2}=0.85\right)$. As expected, $\mathrm{t}$-value is the highest among Temp-based calculation methods for Hargreaves method. $\operatorname{Pr}(>|t|)$ for all methods are low, therefore, the coefficients are significant, and our model is statistically significant. 


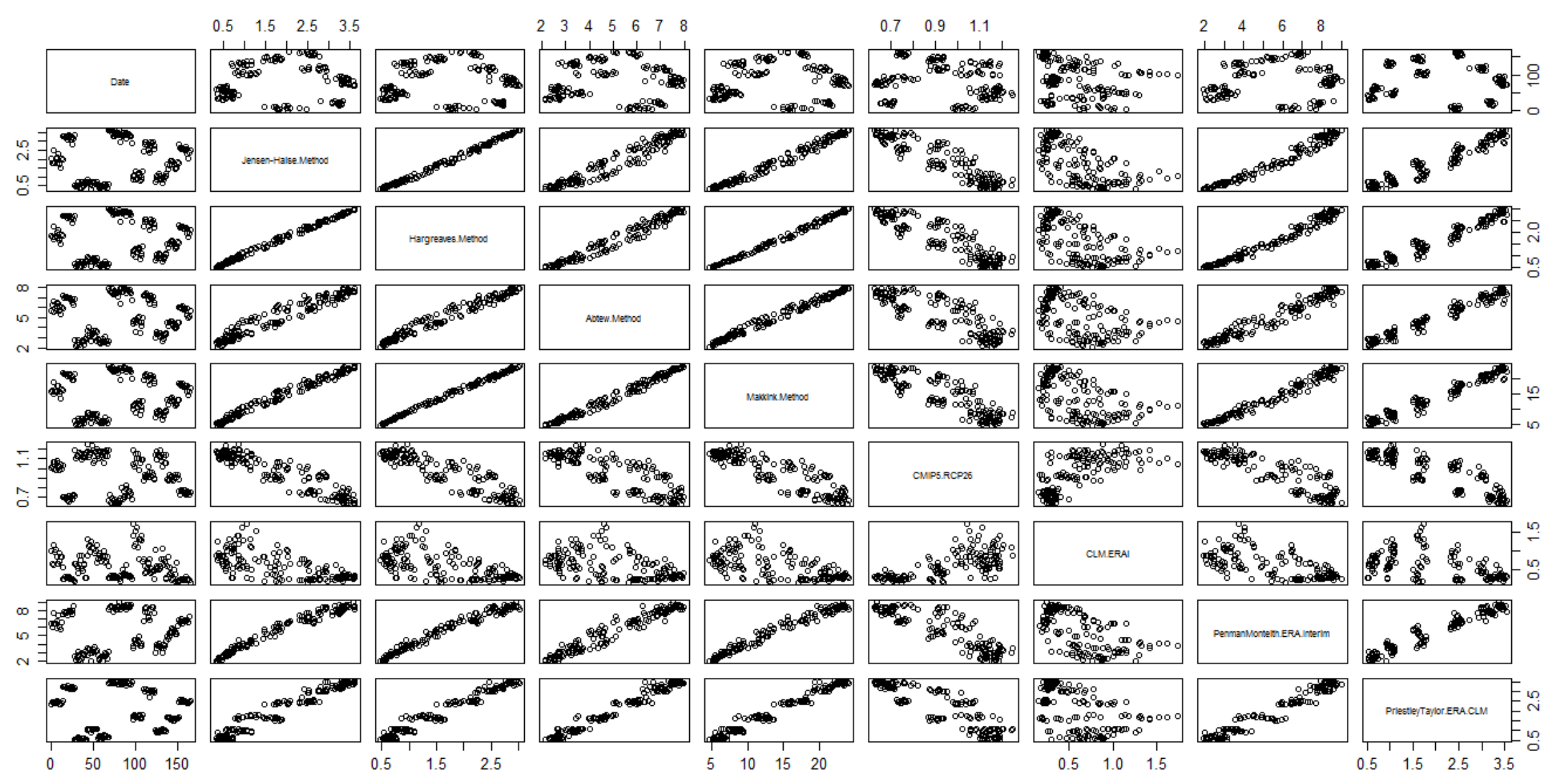

Figure 7. Jensen-Haise, Hargreaves, Makkink and Abtew evapotranspiration values over 165 months are plotted against RCP26-CMIP5, ET-CLMERAi, Penman Monteith- ERA-Interim daily ET $T_{p}$ and Priestley Taylor-ERA-CLM daily ET, where ETs in mm 
Table 6. Descriptive stats: Solar-Based Daily ET $T_{p}$ Methods covering 165 months of observations in comparison to RCP26-CMIP5, CLM-ERAi, Penman-Monteith ERA-Interim and Priestley-Taylor ERA-CLM projections (ET in $\mathrm{mm}$ )

\begin{tabular}{c|c|c|c|c|c|c|c|c}
\hline $\begin{array}{c}\text { Method } \\
\text { Metrids }\end{array}$ & $\begin{array}{c}\text { Jensen- } \\
\text { Maise }\end{array}$ & $\begin{array}{c}\text { Margreaves } \\
\text { Method }\end{array}$ & $\begin{array}{c}\text { Abtew } \\
\text { Method }\end{array}$ & $\begin{array}{c}\text { Makkink } \\
\text { Method }\end{array}$ & $\begin{array}{c}\text { CMIP5. } \\
\text { RCP26 }\end{array}$ & $\begin{array}{l}\text { CLM } \\
\text { ERAi }\end{array}$ & $\begin{array}{c}\text { PenmanMonteith } \\
\text { ERA.Interim }\end{array}$ & $\begin{array}{c}\text { PriestleyTaylor } \\
\text { ERA.CLM }\end{array}$ \\
\hline Min. & 0.3167 & 0.4783 & 2.133 & 4.681 & 0.6257 & 0.1518 & 1.926 & 0.515 \\
1st Qu & 0.7591 & 0.8858 & 3.405 & 8.213 & 0.7462 & 0.2939 & 3.484 & 1.031 \\
Median & 1.7908 & 1.6677 & 5.109 & 14.638 & 0.9542 & 0.5408 & 5.977 & 2.333 \\
Mean & 1.8926 & 1.7081 & 5.136 & 14.370 & 0.9408 & 0.5979 & 5.635 & 2.064 \\
3rd Qu & 2.9441 & 2.5375 & 6.899 & 20.732 & 1.1156 & 0.8370 & 7.892 & 3.18 \\
Max. & 3.6240 & 3.0134 & 7.978 & 24.034 & 1.2475 & 1.7394 & 9.039 & 3.541 \\
NA's & Nil & Nil & Nil & Nil & Nil & Nil & 11 & Nil \\
\hline
\end{tabular}

Table 7. Regression evaluation and validation: Calculated Temperature-Based Daily ET Methods vs. Climate Projections Daily ET

\begin{tabular}{|c|c|c|c|c|c|c|}
\hline \multirow{2}{*}{$\begin{array}{c}\text { Climate Model Projections } \\
\text { Calculated Methods } \\
\text { Metrics } \\
\end{array}$} & \multicolumn{3}{|c|}{$\begin{array}{l}\text { Penman Monteith-ERA Interim } \\
\text { Daily ET (Jan 1979-Jan 1999) }\end{array}$} & \multicolumn{3}{|c|}{$\begin{array}{c}\text { PriestleyTaylor.ERA.CLM (Jan } \\
\text { 1979-Dec 2013) }\end{array}$} \\
\hline & $\begin{array}{l}\text { Hargreaves } \\
\text { Method }\end{array}$ & $\begin{array}{l}\text { Karrufa } \\
\text { Method }\end{array}$ & $\begin{array}{l}\text { Blaney- } \\
\text { Criddle } \\
\text { Method } \\
\end{array}$ & $\begin{array}{l}\text { Hargreaves } \\
\text { Method }\end{array}$ & $\begin{array}{l}\text { Karrufa } \\
\text { Method }\end{array}$ & $\begin{array}{l}\text { Blaney- } \\
\text { Criddle } \\
\text { Method }\end{array}$ \\
\hline Min & -0.77551 & -1.277 & -0.86892 & -0.7162 & -1.06247 & -0.84988 \\
\hline $1 \mathrm{Q}$ & -0.15005 & -0.4846 & -0.25141 & -0.132 & -0.3045 & -0.19236 \\
\hline Median & 0.00624 & -0.1831 & -0.05159 & 0.0024 & 0.01292 & 0.02027 \\
\hline $3 \mathrm{Q}$ & 0.15916 & 0.5081 & 0.22534 & 0.1541 & 0.29793 & 0.20047 \\
\hline $\operatorname{Max}$ & 0.78705 & 1.4569 & 1.17636 & 0.4891 & 0.94618 & 0.64411 \\
\hline \multirow{4}{*}{ Coefficients- } & 0.533191 & 1.65984 & -2.2124 & -0.30481 & 0.265235 & -1.51964 \\
\hline & 0.037633 & 0.0834 & 0.09066 & 0.026747 & 0.041306 & 0.05072 \\
\hline & 14.17 & 19.9 & -24.4 & -11.4 & 6.421 & -29.96 \\
\hline & $<2 \mathrm{e}-16$ & $<2 \mathrm{e}-16$ & $<2 \mathrm{e}-16$ & $<2 \mathrm{e}-16$ & $3.68 \mathrm{e}-10$ & $<2 \mathrm{e}-16$ \\
\hline Estimate & 1.323232 & 1.00954 & 1.77034 & 0.61551 & 0.444624 & 0.79973 \\
\hline \multirow{3}{*}{ Method } & 0.009008 & 0.01878 & 0.01978 & 0.006418 & 0.009065 & 0.01094 \\
\hline & 146.9 & 53.74 & 89.5 & 95.9 & 49.05 & 73.11 \\
\hline & $<2 \mathrm{e}-16$ & $<2 \mathrm{e}-16$ & $<2 \mathrm{e}-16$ & $<2 \mathrm{e}-16$ & $<2 \mathrm{e}-16$ & $<2 \mathrm{e}-16$ \\
\hline Degree of Freedom (months) & 239 & 239 & 239 & 418 & 418 & 418 \\
\hline Residual standard error & 0.2337 & 0.6174 & 0.3801 & 0.2161 & 0.3987 & 0.2791 \\
\hline Multiple R-squared & 0.989 & 0.9236 & 0.971 & 0.9565 & 0.852 & 0.9275 \\
\hline Adjusted R-squared & 0.989 & 0.9233 & 0.9709 & 0.9564 & 0.8516 & 0.9273 \\
\hline F-statistic & $2.158 \mathrm{e}+04$ & 2888 & 8010 & 9197 & 2406 & 5345 \\
\hline $\mathrm{p}$-value (of the linear model) & $<2.2 \mathrm{e}-16$ & $<2.2 \mathrm{e}-16$ & $<2.2 \mathrm{e}-16$ & $<2.2 \mathrm{e}-16$ & $<2.2 \mathrm{e}-16$ & $<2.2 \mathrm{e}-16$ \\
\hline
\end{tabular}


On monthly basis, the temp-based monthly methods showed that the residuals between Hamon, Remanenko and Thornthwaite equations with Priestley Taylor monthly ET are close in values, whereas against Penman Monteith monthly ET, the residuals have wider range. All calculated methods meet the null hypothesis (here it is less than 2e-16 indicating that the model fits the data well. The highest significant positive relationship between monthly Penman Monteith were against monthly Romanenko equation $\left(\mathrm{R}^{2}=0.90\right)$ and Thornthwaite equation $\left(\mathrm{R}^{2}=0.86\right)$ followed by Hamon method $\left(\mathrm{R}^{2}=0.84\right)$. Despite $\mathrm{p}$-Values are considered in statistically significance level (less than 0.05), all monthly calculated Temp-based methods were $\left(\mathrm{R}^{2} \leq 0.80\right)$ against Priestley \& Taylor ERA-CLM monthly ET. t-values are greater than the standard level (1.96), furthermore, the standard error for all equations is close to zero. The best performance was for Romanenko method and Penman Monteith monthly ETs over 239 months with the highest F-statistic (see Table 8).

Table 8. Models Evaluation: Calculated Temperature-Based Monthly ET Methods vs. Climate Projections monthly ET

\begin{tabular}{|c|c|c|c|c|c|c|}
\hline Climate Model Projections & \multicolumn{3}{|c|}{$\begin{array}{l}\text { Penman Monteith-ERA Interim } \\
\text { Monthly ET (Jan 1979-Jan 1999) }\end{array}$} & \multicolumn{3}{|c|}{$\begin{array}{c}\text { PriestleyTaylor.ERA.CLM (Jan } \\
\text { 1979-Dec 2013) }\end{array}$} \\
\hline Calculated Methods & \multicolumn{2}{|c|}{ RomanenkoThornthwaite } & \multirow{2}{*}{$\begin{array}{l}\text { Hamon } \\
\text { Method }\end{array}$} & \multicolumn{2}{|c|}{ RomanenkoThornthwaite } & \multirow{2}{*}{$\begin{array}{l}\text { Hamon } \\
\text { Method }\end{array}$} \\
\hline Metrics & Method & Method & & Method & Method & \\
\hline Min & -62.417 & -49.524 & -55.447 & -67.177 & -42.998 & -30.978 \\
\hline $1 \mathrm{Q}$ & -12.699 & -18.934 & -20.701 & -9.113 & -10.594 & -10.211 \\
\hline Median & -0.618 & -9.913 & -7.642 & 1.105 & -2.515 & -3.981 \\
\hline $3 Q$ & 14.193 & 16.74 & 12.241 & 10.2 & 11.41 & 9.489 \\
\hline Max & 57.836 & 68.51 & 90.839 & 36.991 & 34.318 & 37.919 \\
\hline \multirow{4}{*}{ Coefficients- } & 40.62229 & 84.78962 & 86.57268 & 5.38105 & 24.38735 & 24.741960 \\
\hline & 3.06934 & 2.76806 & 2.94851 & 1.71361 & 1.180 & 1.127674 \\
\hline & 13.23 & 30.63 & 29.36 & 3.14 & 20.66 & 21.94 \\
\hline & $<2 \mathrm{e}-16$ & $<2 \mathrm{e}-16$ & $<2 \mathrm{e}-16$ & 0.00181 & $<2 \mathrm{e}-16$ & $<2 \mathrm{e}-16$ \\
\hline \multirow{4}{*}{ Method } & 0.94796 & 1.53454 & 0.41632 & 0.40016 & 0.66487 & 0.184507 \\
\hline & 0.01999 & 0.03969 & 0.01168 & 0.01077 & 0.016 & 0.004382 \\
\hline & 47.41 & 38.66 & 35.66 & 37.15 & 40.35 & 42.11 \\
\hline & $<2 \mathrm{e}-16$ & $<2 \mathrm{e}-16$ & $<2 \mathrm{e}-16$ & $<2 \mathrm{e}-16$ & $<2 \mathrm{e}-16$ & $<2 \mathrm{e}-16$ \\
\hline Degree of Freedom & 239 & 239 & 239 & 418 & 418 & 418 \\
\hline Residual standard error & 21.44 & 25.68 & 27.52 & 15.41 & 14.44 & 13.96 \\
\hline Multiple R-squared & 0.9039 & 0.8621 & 0.8418 & 0.7675 & 0.7957 & 0.8092 \\
\hline Adjusted R-squared & 0.9035 & 0.8616 & 0.8411 & 0.767 & 0.7952 & 0.8088 \\
\hline F-statistic & 2248 & 1495 & 1271 & 1380 & 1628 & 1773 \\
\hline Model p-value & $<2.2 \mathrm{e}-16$ & $<2.2 \mathrm{e}-16$ & $<2.2 \mathrm{e}-16$ & $<2.2 \mathrm{e}-16$ & $<2.2 \mathrm{e}-16$ & $<2.2 \mathrm{e}-16$ \\
\hline
\end{tabular}




\section{Calculated class-A Pan methods}

There is a stronger significant relationship between both Orange and Allen Kp methods ET against Penman Monteith ERA-Interim ET than against Priestley Taylor ERA-CLM ET values $\left(\mathrm{R}^{2}=0.88 \pm 0.01997,0.87 \pm 0.0217,0.84 \pm 0.00879\right.$ and $0.84 \pm 0.00797$, respectively), see Table 9. All calculated class-A Pan methods' t-Values and p-values met the standard levels, further to standard error are close to zero as illustrated in Table 9. The residuals metrics are approximate between both Orange and Allen Kp methods against Penman and Priestely ET's.

Table 9. Models Evaluation: Calculated Class A Pan ET Methods vs Climate Projections monthly ET

\begin{tabular}{|c|c|c|c|c|c|c|}
\hline \multirow{2}{*}{\multicolumn{3}{|c|}{\begin{tabular}{|c|} 
Climate Model Projections \\
Metrics \\
Calculated Methods
\end{tabular}}} & \multicolumn{2}{|c|}{$\begin{array}{l}\text { Penman Monteith-ERA } \\
\text { Interim ET (Jan 1979-Jan } \\
\text { 1999) }\end{array}$} & \multicolumn{2}{|c|}{$\begin{array}{c}\text { PriestleyTaylor.ERA.CLM (Jan } \\
\text { 1979-Dec 2013) }\end{array}$} \\
\hline & & & $\begin{array}{l}\text { Allen Kp. } \\
\text { Method }\end{array}$ & $\begin{array}{l}\text { Orange Kp } \\
\text { Method }\end{array}$ & Allen Kp Method & $\begin{array}{l}\text { Orange Kp } \\
\text { Method }\end{array}$ \\
\hline & Min & & -72.677 & -76 & -39.496 & -40.08 \\
\hline & $1 \mathrm{Q}$ & & -16.506 & -16.6 & -7.68 & -7.455 \\
\hline & Median & & -0.767 & -0.4 & 0.016 & 0.248 \\
\hline & $3 \mathrm{Q}$ & & 14.285 & 15.11 & 8.344 & 8.178 \\
\hline & Max & & 58.481 & 59.6 & 31.673 & 29.231 \\
\hline \multirow{8}{*}{ Coeffecients } & \multirow{4}{*}{ Intercept } & Estimate & 37.27940 & 37.74438 & 3.363588 & 3.454618 \\
\hline & & Std. Error & 3.64443 & 3.59304 & 1.428525 & 1.384011 \\
\hline & & $\mathrm{t}$ value & 10.23 & 10.51 & 2.355 & 2.496 \\
\hline & & $\operatorname{Pr}(>|t|)$ & 0.00181 & $<2 \mathrm{e}-16$ & 0.019 & 0.0129 \\
\hline & \multirow{4}{*}{ Method } & Estimate & 0.88115 & 0.82066 & 0.406294 & 0.380216 \\
\hline & & Std. Error & 0.02169 & 0.01997 & 0.008793 & 0.007974 \\
\hline & & $\mathrm{t}$ value & 40.62 & 41.10 & 46.208 & 47.682 \\
\hline & & $\operatorname{Pr}(>|t|)$ & $<2 \mathrm{e}-16$ & $<2 \mathrm{e}-16$ & $<2 \mathrm{e}-16$ & $<2 \mathrm{e}-16$ \\
\hline \multicolumn{3}{|c|}{ Degree of Freedom } & 239 & 239 & 418 & 418 \\
\hline \multicolumn{3}{|c|}{ Residual standard error } & 24.6 & 24.35 & 12.93 & 12.59 \\
\hline \multicolumn{3}{|c|}{ Multiple R-squared } & 0.8735 & 0.876 & 0.8363 & 0.8447 \\
\hline \multicolumn{3}{|c|}{ Adjusted R-squared } & 0.873 & 0.8755 & 0.8359 & 0.8443 \\
\hline \multicolumn{3}{|c|}{ F-statistic } & 1650 & 1689 & 2135 & 2274 \\
\hline \multicolumn{3}{|c|}{$\mathrm{p}$-value } & $<2.2 \mathrm{e}-16$ & $<2.2 \mathrm{e}-16$ & $<2.2 \mathrm{e}-16$ & $<2.2 \mathrm{e}-16$ \\
\hline
\end{tabular}

\section{Calculated solar ET methods}

Although disparity changing over time among the solar ET methods, the regression model met the significant linearity correlation between Doorenbos method and both Penman Monteith and Priestley Taylor ERA evapotranspiration (Table 10); $\mathrm{R}^{2}=0.89 \pm 0.028$ and $0.75 \pm 0.019$, respectively. The $\mathrm{t}$-values are greater than the 
standard level furthermore to the lowest $\mathrm{p}$-value $<2.2 \mathrm{e}-16$. The best performance was for Doorenbos method with Penman Monteith ETs over 163 months with the highest Fstatistic.

Table 10. Model Evaluation: Doorenbos Monthly ET vs Climate Models Projections ET

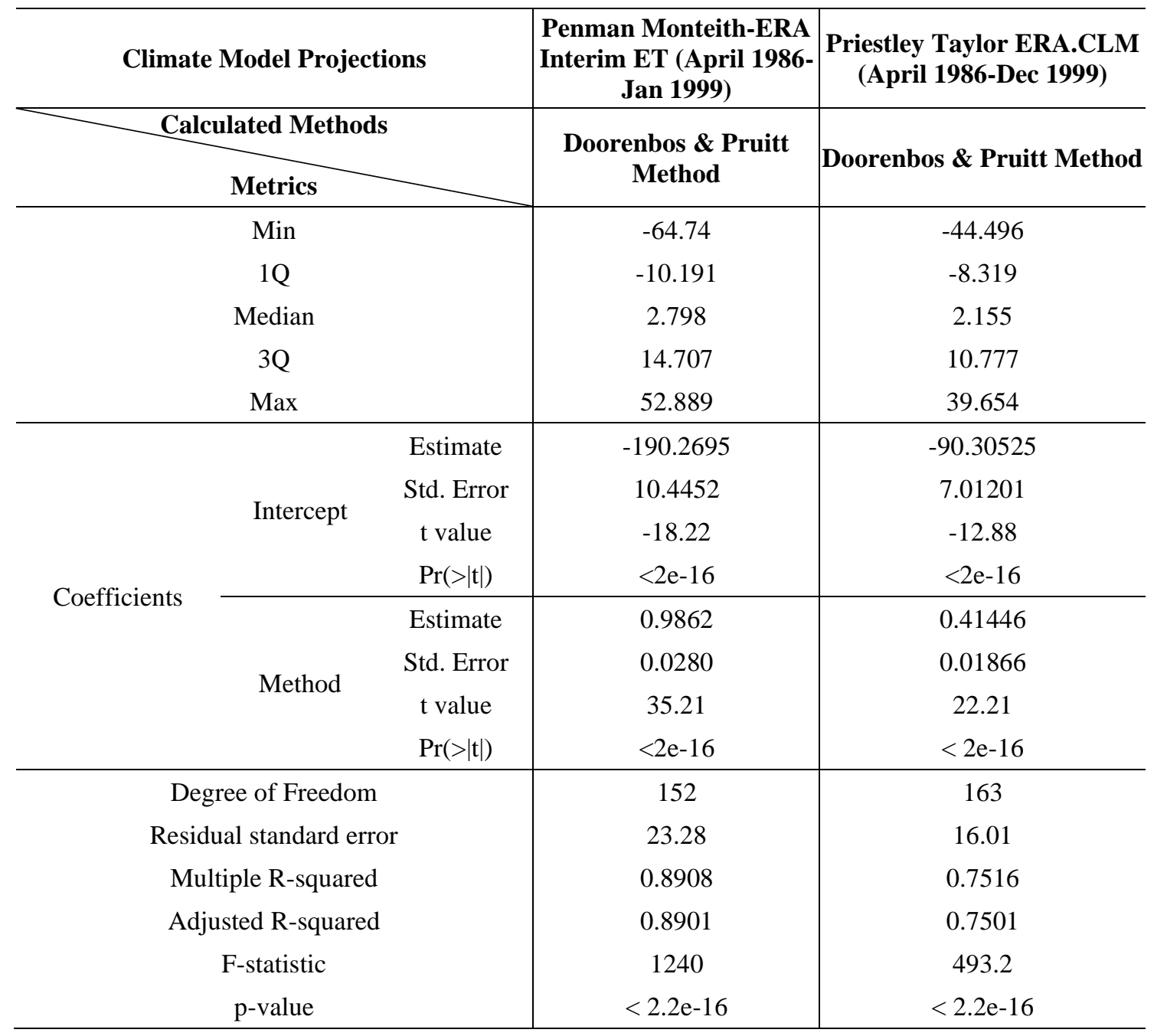

On daily basis, the solar-based ET methods showed in Table 11 the best performance of overall calculated methods $\left(\mathrm{R}^{2} \geq 0.94\right)$. Jensen-Haise, Hargreaves and Makkink equations with Penman Monteith ET are close in minimum residual values, whereas against daily Priestley Taylor ET, the minimum and $1^{\text {st }}$ quartile residuals were approximately the same. All calculated methods meet the null hypothesis (here it is less than 2e-16 indicating that the model fits the data well. The highest significant positive relationship between daily climate projections were against Makkink equation $\left(\mathrm{R}^{2}=0.97\right)$ and Hargreaves equation $\left(\mathrm{R}^{2} \geq 0.96\right)$ followed by Abtew and Jensen-Haise methods $\left(\mathrm{R}^{2} \geq 0.94\right)$. Further to $\mathrm{p}$-Values are considered in statistically significance level (less than $0.05)$, all daily solar calculated ETs had the lower standard errors $(\leq 0.03)$ but the lowest with Makkink and Abtew methods against Priestley Taylor $(\leq 0.008)$. The best performance was for Makkink method and Penman Monteith and Priestly Taylor ETs over 152 months with the highest F-statistic (> 5100). 
Table 11. Models Evaluation: Solar-Based Daily ET Methods vs Penman Monteith-ERA Interim and Priestley Taylor.ERA.CLM evapotranspiration values

\begin{tabular}{|c|c|c|c|c|c|c|c|c|c|c|}
\hline \multirow{2}{*}{\multicolumn{3}{|c|}{\begin{tabular}{|} 
Climate Model Projections \\
Metrics \\
\end{tabular}}} & \multicolumn{4}{|c|}{$\begin{array}{c}\text { Penman Monteith-ERA Interim Monthly ET (April } \\
\text { 1986-Jan 1999) }\end{array}$} & \multicolumn{4}{|c|}{ PriestleyTaylor.ERA.CLM (April 1986-Dec 1999) } \\
\hline & & & $\begin{array}{l}\text { Jensen-Haise } \\
\text { Method }\end{array}$ & $\begin{array}{l}\text { Hargreaves } \\
\text { Method }\end{array}$ & $\begin{array}{l}\text { Abtew } \\
\text { Method }\end{array}$ & $\begin{array}{l}\text { Makkink } \\
\text { Method }\end{array}$ & $\begin{array}{l}\text { Jensen-Haise } \\
\text { Method }\end{array}$ & $\begin{array}{l}\text { Hargreaves } \\
\text { Method }\end{array}$ & Abtew Method & $\begin{array}{l}\text { Makkink } \\
\text { Method }\end{array}$ \\
\hline & Min & & -0.8635 & -0.85795 & -1.2626 & -0.79449 & -0.52263 & -0.44514 & -0.50917 & -0.3997 \\
\hline & $1 \mathrm{Q}$ & & -0.3493 & -0.25148 & -0.33113 & -0.24999 & -0.18776 & -0.12476 & -0.13366 & -0.10961 \\
\hline & Median & & -0.0758 & -0.06105 & -0.00107 & -0.07696 & -0.04631 & -0.02944 & -0.02323 & -0.00655 \\
\hline & 3Q & & 0.3219 & 0.23482 & 0.29344 & 0.19681 & 0.15095 & 0.11441 & 0.10599 & 0.08775 \\
\hline & Max & & 0.994 & 0.96988 & 1.65621 & 1.20678 & 0.64032 & 0.61355 & 0.74275 & 0.59853 \\
\hline \multirow{8}{*}{ Coefficients } & \multirow{4}{*}{ Intercept } & Estimate & 1.88334 & 1.1398 & -0.40943 & 0.613019 & 0.34135 & -0.01519 & -0.78236 & -0.27023 \\
\hline & & Std. Error & 0.0694 & 0.07016 & 0.12937 & 0.076557 & 0.04019 & 0.03658 & 0.043747 & 0.03507 \\
\hline & & t value & 27.14 & 16.25 & -3.165 & 8.007 & 8.494 & -0.415 & -17.88 & -7.705 \\
\hline & & $\operatorname{Pr}(>|t|)$ & $<2 \mathrm{e}-16$ & $<2 \mathrm{e}-16$ & 0.00187 & $2.83 \mathrm{e} 13$ & $1.19 \mathrm{E}-14$ & 0.678 & $<2 \mathrm{e}-16$ & $1.2 \mathrm{e}-12$ \\
\hline & \multirow{4}{*}{ Method } & Estimate & 1.98913 & 2.63713 & 1.17675 & 0.349923 & 0.90995 & 1.217 & 0.55408 & 0.162403 \\
\hline & & Std. Error & 0.03169 & 0.03689 & 0.02368 & 0.004878 & 0.01835 & 0.01924 & 0.008019 & 0.002236 \\
\hline & & t value & 62.76 & 71.48 & 49.692 & 71.738 & 49.591 & 63.245 & 69.09 & 72.625 \\
\hline & & $\operatorname{Pr}(>|t|)$ & $<2 \mathrm{e}-16$ & $<2 \mathrm{e}-16$ & $<2 \mathrm{e}-16$ & $<2 \mathrm{e}-16$ & $<2 \mathrm{e}-16$ & $<2 \mathrm{e}-16$ & $<2 \mathrm{e}-16$ & $<2 \mathrm{e}-16$ \\
\hline \multicolumn{3}{|c|}{ Degree of Freedom } & 152 & 152 & 152 & 152 & 163 & 163 & 163 & 163 \\
\hline \multicolumn{3}{|c|}{ Residual standard error } & 0.4378 & 0.3861 & 0.547 & 0.3847 & 0.2598 & 0.2062 & 0.1893 & 0.1804 \\
\hline \multicolumn{3}{|c|}{ Multiple R-squared } & 0.9628 & 0.9711 & 0.942 & 0.9713 & 0.9378 & 0.9608 & 0.967 & 0.97 \\
\hline \multicolumn{3}{|c|}{ Adjusted R-squared } & 0.9626 & 0.9709 & 0.9416 & 0.9711 & 0.9375 & 0.9606 & 0.9668 & 0.9698 \\
\hline \multicolumn{3}{|c|}{ F-statistic } & 3939 & 5109 & 2469 & 5146 & 2459 & 4000 & 4774 & 5274 \\
\hline \multicolumn{3}{|c|}{ p-value } & $<2.2 \mathrm{e}-16$ & $<2.2 \mathrm{e}-16$ & $<2.2 \mathrm{e}-16$ & $<2.2 \mathrm{e}-16$ & $<2.2 \mathrm{e}-16$ & $<2.2 \mathrm{e}-16$ & $<2.2 \mathrm{e}-16$ & $<2.2 \mathrm{e}-16$ \\
\hline
\end{tabular}




\section{Data Distribution}

To compare the distributions of data groups, daily and monthly boxplots are representing in Fig. 8 and showed the most common data values and change over time among models. Regarding comparison, the solar-based ET, the ends of the daily boxplots outlined the similarity between Penman Monteith and Abtew methods as well as between Jensen-Haise and Hargreaves ETs, in addition to the central $50 \%$ of the data are almost the same for these models whereas the spread of data for Makkink was different. JensenHaise and Hargreaves vs Priestley Taylor ET values showed the approximate ends of daily boxplot, however, the same central $50 \%$ of its data. The ends of the daily boxplots, as well as the central $50 \%$ of the data, outlined the difference between Makkink and Abtew methods against Priestley Taylor ERA projections (see Fig. 8a).

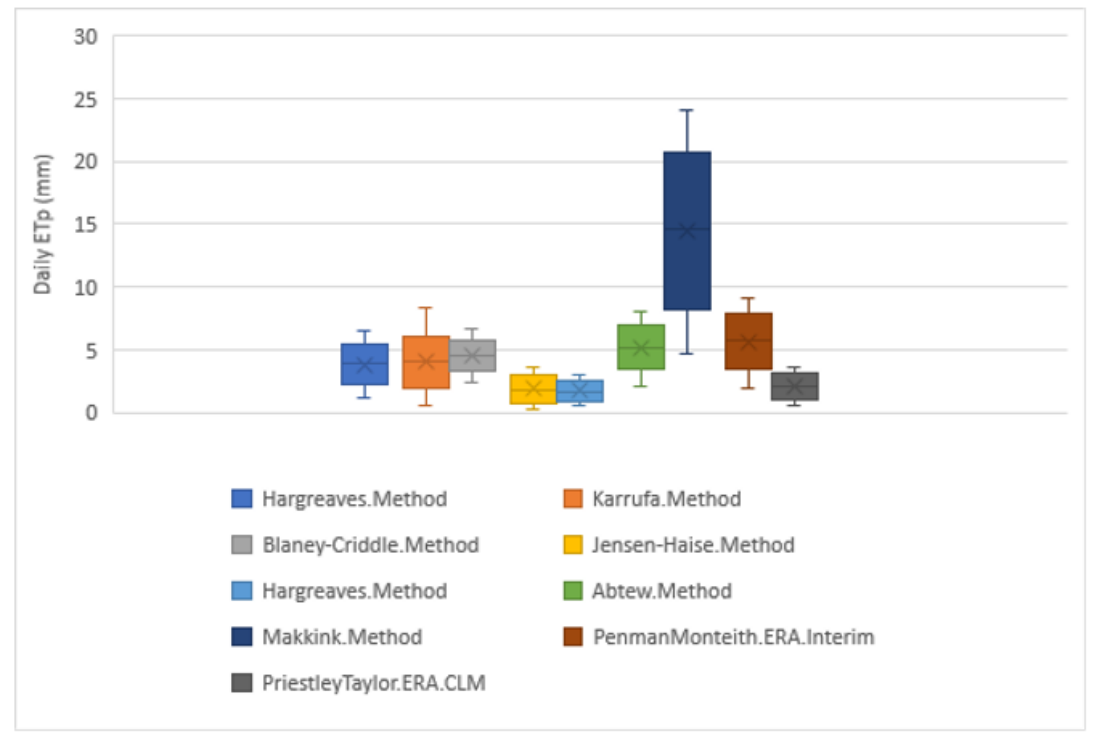

(a)

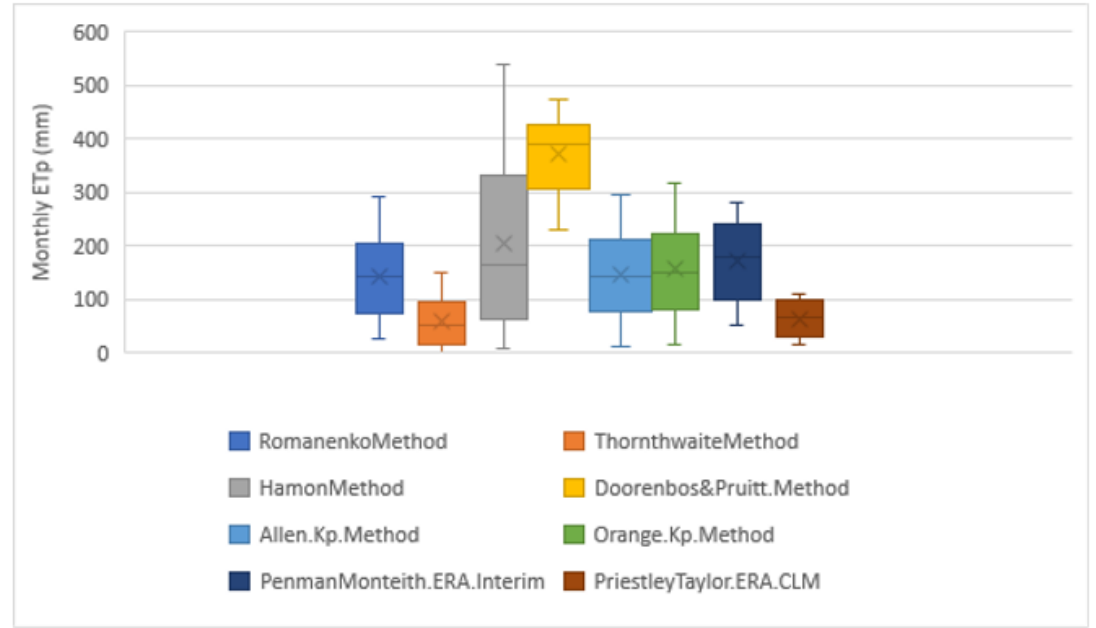

(b)

Figure 8. (a) Boxplot's data distribution over time for temperature-based, solar-based and Class-A Pan methods on monthly basis with respect to Penman Monteith and Priestley Taylor climate models projections of Ets. (b) Boxplot's data distribution over time for temperaturebased, and solar-based methods on daily basis with respect to Penman Monteith and Priestley Taylor climate models projections of ETs 
On monthly basis in Fig. $8 b$, the ends of the monthly box outlined the similarity between Penman Monteith and Romanenko methods but shorter maximum ending for Thornthwaite method. The central 50\% of the data are almost the same for Romanenko, Hamon and Penman Monteith methods. Whereas the spread of data for Priestly Taylor and Thornthwaite showed the approximate ends of monthly boxplot, however, the same central $50 \%$ of Romanenko and Hamon data with different maximum ends. The results characterized the difference in range and the central 50\% of the data between Doorenbos and Pruitt method against climate models ET values during more than 150 months.

The ends of the Kp Pan methods box outlined the similarity between Orange Kp and Allen Kp evapotranspiration methods but shorter maximum and minimum endings for Penman method. The central 50\% of the data are almost the same for Orange Kp, Allen $\mathrm{Kp}$ and Penman Monteith methods, whereas very narrower spread of data for Priestly Taylor, as shown in Fig. $8 b$.

\section{Discussion}

Since $\mathrm{ET}_{\mathrm{p}}$ is difficult to estimate accurately, rigorous calculations should be considered because of its importance for estimating actual water loss from natural systems as well in hydrological studies. This study gave wide range of values and suggested the ET $_{\mathrm{p}}$ variations among 13 calculation models across the study area in the middle of JordanAmman. The study adopted four climate models projections as benchmark due to unavailable actual ET values.

ERA-Interim data are used for 20 years of measurements flights which extended regionally and covered the study area (Kunz et al., 2014; Philip et al., 2020). The selection of ERA-Interim as benchmark data was based on previous studies and its emphasis on terrestrial ET. Bai and Liu (2018), for example, concluded the best performance of ERAinterim with observations as one of the most consistent global high-resolution ET products. This was due to the effect of soil water stress on ET depend on soil moisture balance model (Martens et al., 2016) which made ERA-Interim ET product is an asset to benefit regional water users (Baik et al., 2018; Wang et al., 2019). Not to mention the good agreement between ERA-Interim and the high quality water vapor dataset is evaluated by Kunz's experiment (Kunz et al., 2014).

This study showed how changes in climatic conditions will change evapotranspiration. Through all the scatter plots and descriptive stats, CMIP5-RCP26 and CLM-ERAi showed a performance in the projections that might change as a function of the state of climate. Climate models CMIP5-RCP26 (Al-Shibli, 2018) and CLM-ERAi did not weight the evaporation in proportion to the season, as ET estimates are overestimated in winter and underestimated in summer months. This can be justified by the combined effect of soil moisture content and evapotranspiration on temperature and cloud cover. The latent heat flux incorporated with evaporation causes decreasing of land net radiation. Simply put, while ET decreases, the temperature rises (Mueller and Seneviratne, 2014; Dosio et al., 2021). Another explanation to the reversal effect of greenhouse gases concentrations that boost the changes in hydrological cycle, it decreases the precipitation and evapotranspiration due to the increasing weight of aerosols (Roeckner et al., 1999; Calanca et al., 2006).

Calculation methods showed that benchmarking ET $_{\mathrm{p}}$ of Penman-Monteith ERA Interim come close to previous studies. Al Mahamid (2005) calculated the long-term average of $\mathrm{ET}_{\mathrm{p}}$ for the period from 1970 to 2001 Amman-Zarqa Basin, according to 
Penman-Monteith equation, between (65-170) $\mathrm{mm} / \mathrm{month}$ during winter $(173.00 \mathrm{~mm} / \mathrm{month}$ for ERA Interim) and (129-250) $\mathrm{mm} / \mathrm{month}$ during summer (264.5 mm/month for ERA Interim). As Doorenbos (1977) and Al Mahamid (2005) found the high correlation between actual ET and class A-pan evaporation ET, this study proved 75 percentile of Allen and Orange potential pan ET pan values are approximate to Doorenbos \& Pruitt minimum ETs while the latter maximum ETs are similar to maximum Allen ET $_{\mathrm{p}}$. Since Penman-Monteith equation was adopted even under missing data conditions, the reliability of Penman-Monteith method was verified at site and catchment scales in humid and semi-humid conditions but showed less reliable in semi-arid region as it is overly controlled by precipitation (Zhang et al., 2008). Alternative methods such as Hargreaves, Abtew, and Jensen-Haise could be used in semi-arid dry land as being reported by Djaman et al. (2019) and Hargreaves ET results under aridity conditions are better across Mediterranean region (Todorovic et al., 2013). The ET sharing component in water balance, however, was calculated also by using Shuttleworth-Wallace equation for the lower part of Jordan river basin, it was $72 \%$ of the rain as $269 \mathrm{~mm} / \mathrm{year}$ during 2002-2003 (Gunkel and Lange, 2012). The minimum values of $\mathrm{ET}_{\mathrm{p}}$ in Priestley Taylor ERA-CLM projections during short period from April 1986 to Dec 1999 showed higher ET than the values during the longer time slice from Jan 1979 to Dec 2013 as the lowest value is not overlapping within the short time slice comparison.

In our study, ET exceeds the total precipitation since no water body available in the study area except small dams and streams. Thornthwaite and Mather method was used to estimate potential ET in the northern parts of Jordan (Almagbile et al., 2019), where the study found the correlation that the higher ET the lower observed soil moisture. The solar radiation methods to calculate ET showed the best performance, among others. This analysis recommended as same as Valle Júnior's research (Valle Júnior et al., 2020) which recommended investing in radiation research for ET estimation simpler than using more data inputs for Penman-Monteith formula.

\section{Conclusion and Recommendations}

Clearly, some models to estimate $\mathrm{ET}_{\mathrm{p}}$ evidence significant trends to climate parameters aligned with the direction of the change whether changing in temperature degrees or radiation energy. The study showed that $\mathrm{ET}_{\mathrm{p}}$ estimation method' accurecy and applicability is likely to be site-specific.

Linear regression analysis between the standard ETs of climate models' outputs and the modelled potential ETs were performed. The analysis showed asymmetry between both CMIP5-RCP 2.6 and CLM-ERAi outputs and calculated ETs but inconsistent with Penman Monteith ERA Interim and Priestley Taylor ERA-CLM. Climate models CMIP5RCP26 and CLM-ERAi did not weight the evapotranspiration in proportion to the season and showing inverse proportional to the trend of ETs which might be because of the combined effects of soil moisture content and ET on temperature and heat fluxes.

Penman Monteith ERA-Interim demonstrates the literature values that vary from 51 to $280 \mathrm{~mm} / \mathrm{month}$. Blaney Criddle and Hargreaves temperature-based and solar based methods prototyped the potential evapotranspiration $\left(\mathrm{R}^{2}=0.99-0.97\right)$ followed by Makkink and Jensen-Haise radiation-based formulas $\left(\mathrm{R}^{2}=0.97-0.96\right)$ which showed the best fitted with ERA climate models evapotranspiration. The remaining models need to be calibrated under the local conditions due to its limitation in the current constants. These results help to decide which method to estimate $\mathrm{ET}_{\mathrm{p}}$ depending on the availability of data 
required per each equation. Radiation-based methods like Hargreaves, Makkink and Jensen-Haise equations are recommended if temperature and radiation data is available. Otherwise, temperature-based methods like Blaney Criddle and Hargreaves are recommended if temperature data is the only available observations. ERA-reanalysis proved capability to perform better in the study area with temporal consistency since it relies on ECMWF heat fluxes. Therefore, Penman Monteith- ERA-Interim and Priestley Taylor-ERA-CLM ET $\mathrm{p}$, however, could be used instead for $\mathrm{ET}_{\mathrm{p}}$ estimation in hydrometeorological modelling and actual water loss studies.

The ET trends showed the sensitivity of evapotranspiration to temperature and radiation more than the remaining meteorological parameters. Further work is needed for GCM/RCM models which cropped large grids and transferable coupling of its projections to a particular site should be considered and tested in the absence of reference values of models' parameters in sub-grid studies.

Funding. This research received fund from Australian Government - Direct Aid Program (DAP)Department of Foreign Affairs and Trade and The Scientific Research Council -University of Jordan.

Data Availability Statement. Datasets will be provided upon request.

Acknowledgments. I appreciate the climate modelling groups for making their models outputs available: CMIP5-RCP 2.6, CLM-ERAi, ERA Interim, and ERA-CLM.

Conflicts of Interests. The authors declare no conflict of interests.

\section{REFERENCES}

[1] Abtew, W. (1996): Evapotranspiration measurements and modeling for three wetland systems in South Florida. - JAWRA J. Am. Water Resour. Assoc. 32(3): 465-473.

[2] Ahmad, M. A. B. (2013): Mining Health Data for Breast Cancer Diagnosis Using Machine Learning. - Doctoral thesis, Univ. of Canberra.

[3] Akhavan, S., Kanani, E., Dehghanisanij, H. (2019): Assessment of different reference evapotranspiration models to estimate the actual evapotranspiration of corn (Zea mays L.) in a semiarid region (case study, Karaj, Iran). - Theor. Appl. Climatol. 137: 1403-1419.

[4] Al Mahamid, J. (2005): Integration of water resources of the upper aquifer in AmmanZarqa basin based on mathematical modeling and GIS, Jordan. - Inst. für Geologie.

[5] Al-Shibli, F. M., Maher, W. A., Thompson, R. M. (2017): The Need for a Quantitative Analysis of Risk and Reliability for Formulation of Water Budget in Jordan. - JJEES, Jordan J. Earth Environ. Sci. 8: 77-89.

[6] Al-Shibli, F. M. (2018): Modelling a Future Water Budget in the Amman-Zarqa Basin, Jordan: Evaluation of the Major Stressors Affecting Water Availability. - University of Canberra.

[7] Allen, R. G. (1995): Evaluation of procedures for estimating mean monthly solar radiation from air temperature. - AGRIS, Food and Agriculture Organization of the United Nations.

[8] Allen, R. G., Pereira, L. S., Raes, D., Smith, M. (1998): Crop evapotranspiration Guidelines for computing crop water requirements. - FAO Irrigation and drainage paper 56. FAO, Rome 300, D05109.

[9] Almagbile, A., Zeitoun, M., Hazaymeh, K., Sammour, H. A., Sababha, N. (2019): Statistical analysis of estimated and observed soil moisture in sub-humid climate in northwestern Jordan. - Environ. Monit. Assess. 191: 96.

[10] Bai, P., Liu, X. (2018): Intercomparison and evaluation of three global high-resolution 
evapotranspiration products across China. - J. Hydrol. 566: 743-755.

[11] Baik, J., Liaqat, U. W., Choi, M. (2018): Assessment of satellite-and reanalysis-based evapotranspiration products with two blending approaches over the complex landscapes and climates of Australia. - Agric. For. Meteorol. 263: 388-398.

[12] Bautista, F., Bautista, D., Delgado-Carranza, C. (2009): Calibration of the equations of Hargreaves and Thornthwaite to estimate the potential evapotranspiration in semi-arid and subhumid tropical climates for regional applications. - Atmósfera 22: 331-348.

[13] Bayazit, M., Önöz, B. (2007): To prewhiten or not to prewhiten in trend analysis? - Hydrol. Sci. J. 52: 611-624.

[14] Blaney, H. F. (1952): Determining water requirements in irrigated areas from climatological and irrigation data. - AGRIS, Food and Agriculture Organization of the United Nations.

[15] Blaney, H. F., Criddle, W. D. (1962): Determining consumptive use and irrigation water requirements. - US Department of Agriculture.

[16] Bormann, H. (2011): Sensitivity analysis of 18 different potential evapotranspiration models to observed climatic change at German climate stations. - Clim. Change 104: 729753.

[17] Burek, P., van der Knijff, J., Ntegeka, V. (2013): LISVAP evaporation pre-processor for the LISFLOOD water balance and flood simulation model. - User Manual.

[18] Calanca, P., Roesch, A., Jasper, K., Wild, M. (2006): Global warming and the summertime evapotranspiration regime of the Alpine region. - Clim. Change 79: 65-78.

[19] Comair, G. F., McKinney, D. C., Siegel, D. (2012): Hydrology of the Jordan River Basin: Watershed delineation, precipitation and evapotranspiration. - Water Resour. Manag. 26: 4281-4293.

[20] de Lima, J. A. G., Alcântara, C. R. (2019): Comparison between ERA Interim/ECMWF, CFSR, NCEP/NCAR reanalysis, and observational datasets over the eastern part of the Brazilian Northeast Region. - Theor. Appl. Climatol. 138: 2021-2041.

[21] Dee, D. P., Uppala, S. M., Simmons, A. J., Berrisford, P., Poli, P., Kobayashi, S., Andrae, U., Balmaseda, M. A., Balsamo, G., Bauer, P. (2011): The ERA-Interim reanalysis: Configuration and performance of the data assimilation system. - Q. J. R. Meteorol. Soc. 137(656): 553-597.

[22] Dingre, S. K., Gorantiwar, S. D. (2020): Determination of the water requirement and crop coefficient values of sugarcane by field water balance method in semiarid region. - Agric. water Manag. 232: 106042.

[23] Djaman, K., O’Neill, M., Diop, L., Bodian, A., Allen, S., Koudahe, K., Lombard, K. (2019): Evaluation of the Penman-Monteith and other 34 reference evapotranspiration equations under limited data in a semiarid dry climate. - Theor. Appl. Climatol. 137: 729743.

[24] Doorenbos, J. (1977): Guidelines for predicting crop water requirements. - FAO Irrig. Drain. Pap. 24: 1-179.

[25] Dosio, A., Jury, M. W., Almazroui, M., Ashfaq, M., Diallo, I., Engelbrecht, F. A., Klutse, N. A. B., Lennard, C., Pinto, I., Sylla, M. B., Tamoffo, A. T. (2021): Projected future daily characteristics of African precipitation based on global (CMIP5, CMIP6) and regional (CORDEX, CORDEX-CORE) climate models. - Clim. Dyn. 57: 3135-3158.

[26] Duffy, K. A., Schwalm, C. R., Arcus, V. L., Koch, G. W., Liang, L. L., Schipper, L. A. (2021): How close are we to the temperature tipping point of the terrestrial biosphere? Sci. Adv. 7: eaay 1052 .

[27] Fernández, M. D., Bonachela, S., Orgaz, F., Thompson, R., López, J. C., Granados, M. R., Gallardo, M., Fereres, E. (2010): Measurement and estimation of plastic greenhouse reference evapotranspiration in a Mediterranean climate. - Irrig. Sci. 28: 497-509.

[28] Flato, G., Marotzke, J., Abiodun, B., Braconnot, P., Chou, S. C., Collins, W. J., Cox, P., Driouech, F., Emori, S., Eyring, V. (2013): Evaluation of climate models. - In: Climate Change 2013: The physical science basis. Contribution of working group I to the fifth 
assessment report of the intergovernmental panel on climate change. Clim. Chang. 2013 5: 741-866.

[29] Gomariz-Castillo, F., Alonso-Sarria, F., Cabezas-Calvo-Rubio, F. (2018): Calibration and spatial modelling of daily ET 0 in semiarid areas using Hargreaves equation. - Earth Sci. Informatics 11: 325-340.

[30] Guerschman, J. P., Van Dijk, A.I.J.M., Mattersdorf, G., Beringer, J., Hutley, L.B., Leuning, R., Pipunic, R.C., Sherman, B. S. (2009): Scaling of potential evapotranspiration with MODIS data reproduces flux observations and catchment water balance observations across Australia. - J. Hydrol. 369: 107-119.

[31] Gunkel, A., Lange, J. (2012): New insights into the natural variability of water resources in the Lower Jordan River Basin. - Water Resour. Manag. 26: 963-980.

[32] Hamon, W. R. (1963): Computation of direct runoff amounts from storm rainfall. - Int. Assoc. Sci. Hydrol. Publ. 63: 52-62.

[33] Hansen, S. (1984): Estimation of Potential and Actual Evapotranspiration: Paper presented at the Nordic Hydrological Conference (Nyborg, Denmark, August-1984). - Hydrol. Res. 15: 205-212.

[34] Hargreaves, G. L., Hargreaves, G. H., Riley, J. P. (1985): Agricultural benefits for Senegal River basin. - J. Irrig. Drain. Eng. 111: 113-124.

[35] Hargreaves, G. H. (1994): Defining and using reference evapotranspiration. - J. Irrig. Drain. Eng. 120: 1132-1139.

[36] Hargreaves, G. H., Allen, R. G. (2003): History and evaluation of Hargreaves evapotranspiration equation. - J. Irrig. Drain. Eng. 129: 53-63.

[37] Jensen, M. E., Haise, H. R. (1963): Estimating evapotranspiration from solar radiation. Proc. Am. Soc. Civ. Eng. J. Irrig. Drain. Div. 89: 15-41.

[38] Kharrufa, N. S. (1985): Simplified equation for evapotranspiration in arid regions. Beiträge zur Hydrol. 5: 39-47.

[39] Kunz, A., Spelten, N., Konopka, P., Müller, R., Forbes, R. M., Wernli, H. (2014): Comparison of Fast in situ Stratospheric Hygrometer (FISH) measurements of water vapor in the upper troposphere and lower stratosphere (UTLS) with ECMWF (re) analysis data. - Atmos. Chem. Phys. 14: 10803-10822.

[40] Lu, J., Sun, G., McNulty, S. G., Amatya, D. M. (2005): A Comparison of Six Potential Evapotranspiration Methods for Regional Use in the Southeastern United States. - JAWRA J. Am. Water Resour. Assoc. 41: 621-633.

[41] Makkink, G. F. (1957): Testing the Penman formula by means of lysimeters. - J. Inst. Water Eng. 11: 277-288.

[42] Martens, B., Miralles, D. G., Lievens, H., van der Schalie, R., de Jeu, R. A. M., FernándezPrieto, D., Beck, H. E., Dorigo, W. A., Verhoest, N. E. C. (2016): GLEAM v3: Satellitebased evaporation and root-zone soil moisture. - Geosci. Model Dev. Discuss. 10: 19031925.

[43] Monteith, J. L. (1965): Evaporation and environment. - Symposia of the Society for Experimental Biology, pp. 205-234.

[44] Mueller, B., Seneviratne, S. I. (2014): Systematic land climate and evapotranspiration biases in CMIP5 simulations. - Geophys. Res. Lett. 41: 128-134.

[45] Nahar, K. M. O., Ottom, M. A., Alshibli, F., Shquier, M. M. A. (2020): Air Quality Index Using Machine Learning--A Jordan Case Study. - Compusoft 9: 3831-3840.

[46] Ogunrinde, A. T., Olasehinde, D. A., Olotu, Y. (2020): Assessing the sensitivity of standardized precipitation evapotranspiration index to three potential evapotranspiration models in Nigeria. - Sci. African 8: e00431.

[47] Orang, M. (1998): Potential accuracy of the popular non-linear regression equations for estimating pan coefficient values in the original and FAO-24 tables. - Unpubl. Rep., Calif. Dept. Water Resour. Sacramento.

[48] Padrón, R. S., Gudmundsson, L., Decharme, B., Ducharne, A., Lawrence, D. M., Mao, J., Peano, D., Krinner, G., Kim, H., Seneviratne, S. I. (2020): Observed changes in dry-season 
water availability attributed to human-induced climate change. - Nat. Geosci. 13: 477-481.

[49] Philip, S. Y., Kew, S. F., van der Wiel, K., Wanders, N., van Oldenborgh, G. J. (2020): Regional differentiation in climate change induced drought trends in the Netherlands. Environ. Res. Lett. 15: 94081.

[50] Priestley, C. H. B., Taylor, R. J. (1972): On the assessment of surface heat flux and evaporation using large-scale parameters. - Mon. Weather Rev. 100: 81-92.

[51] Rahimikhoob, A., Hosseinzadeh, M. (2014): Assessment of Blaney-Criddle equation for calculating reference evapotranspiration with NOAA/AVHRR data. - Water Resour. Manag. 28: 3365-3375.

[52] Roeckner, E., Bengtsson, L., Feichter, J., Lelieveld, J., Rodhe, H. (1999): Transient climate change simulations with a coupled atmosphere--ocean GCM including the tropospheric sulfur cycle. - J. Clim. 12: 3004-3032.

[53] Romanenko, V. A. (1961): Computation of the autumn soil moisture using a universal relationship for a large area. - Proc. Ukr. Hydrometeorol. Res. Inst. 3: 12-25.

[54] Sabziparvar, A.-A., Tabari, H. (2010): Regional estimation of reference evapotranspiration in arid and semiarid regions. - J. Irrig. Drain. Eng. 136: 724-731.

[55] Samaras, D. A., Reif, A., Theodoropoulos, K. (2014): Evaluation of radiation-based reference evapotranspiration models under different Mediterranean climates in central Greece. - Water Resour. Manag. 28: 207-225.

[56] Sasireka, K., Reddy, C. J. M., Reddy, C. C., Ramakrishnan, K. (2017): Evaluation and Recalibration of Empirical Constant for Estimation of Reference Crop Evapotranspiration against the Modified Penman Method. - In: IOP Conference Series: Earth and Environmental Science. IOP Publishing.

[57] Shahin, M. (2007): Water resources and hydrometeorology of the Arab region. - Springer Science \& Business Media.

[58] Simmons, A. J., Jones, P. D., da Costa Bechtold, V., Beljaars, A. C. M., Kållberg, P. W., Saarinen, S., Uppala, S. M., Viterbo, P., Wedi, N. (2004): Comparison of trends and lowfrequency variability in CRU, ERA-40, and NCEP/NCAR analyses of surface air temperature. - J. Geophys. Res. Atmos. 109(D24).

[59] Stocker, T. F., Qin, D., Plattner, G. K., Tignor, M., Allen, S. K., Boschung, J., Nauels, A., Xia, Y., Bex, B., Midgley, B. M. (2013): IPCC, 2013: Climate Change 2013: the physical science basis. - Contribution of working group I to the fifth assessment report of the intergovernmental panel on climate change.

[60] Szilagyi, J., Parlange, M. B., Katul, G. G. (2014): Assessment of the Priestley-Taylor parameter value from ERA-Interim global reanalysis data. - J. Hydrol. Environ. Res 2: 17.

[61] Tabari, H., Grismer, M. E., Trajkovic, S. (2013): Comparative analysis of 31 reference evapotranspiration methods under humid conditions. - Irrig. Sci. 31: 107-117.

[62] Talaee, P. H. (2014): Performance evaluation of modified versions of Hargreaves equation across a wide range of Iranian climates. - Meteorol. Atmos. Phys. 126: 65-70.

[63] Thornthwaite, C. W. (1948): An approach toward a rational classification of climate. Geogr. Rev. 38: 55-94.

[64] Todorovic, M., Karic, B., Pereira, L. S. (2013): Reference evapotranspiration estimate with limited weather data across a range of Mediterranean climates. - J. Hydrol. 481: 166-176.

[65] Trajkovic, S., Kolakovic, S. (2009): Evaluation of reference evapotranspiration equations under humid conditions. - Water Resour. Manag. 23: 3057.

[66] Trouet, V., Van Oldenborgh, G. J. (2013): KNMI Climate Explorer: a web-based research tool for high-resolution paleoclimatology. - Tree-Ring Res. 69: 3-13.

[67] Uppala, S., Dee, D., Kobayashi, S., Berrisford, P., Simmons, A. (2008): Towards a climate data assimilation system: Status update of ERA-Interim. - ECMWF Newsl. 115: 12-18.

[68] Valle Júnior, L. C. G., Ventura, T. M., Gomes, R. S. R., de S. Nogueira, J., de A. Lobo, F., Vourlitis, G. L., Rodrigues, T. R. (2020): Comparative assessment of modelled and empirical reference evapotranspiration methods for a Brazilian savanna. - Agric. Water 
Manag. 232: 106040.

[69] Wang, S., Zhang, M., Sun, M., Wang, B., Huang, X., Wang, Q., Feng, F. (2015): Comparison of surface air temperature derived from NCEP/DOE R2, ERA-Interim, and observations in the arid northwestern China: a consideration of altitude errors. - Theor. Appl. Climatol. 119: 99-111.

[70] Wang, Y., Li, R., Min, Q., Fu, Y., Wang, Y., Zhong, L., Fu, Y. (2019): A three-source satellite algorithm for retrieving all-sky evapotranspiration rate using combined optical and microwave vegetation index at twenty AsiaFlux sites. - Remote Sens. Environ. 235: 111463.

[71] Wartena, L. (1959): The climate and the evaporation from a lake in central Iraq. - Meded. van Landbouwhogesch. 59: 1-59.

[72] Wickham, H., Grolemund, G. (2016): R for data science: import, tidy, transform, visualize, and model data. - O'Reilly Media, Inc.

[73] Xu, C. (2002): Hydrologic models. - Textb. Uppsala Univ. Dep. Earth Sci. Hydrol.

[74] Xu, C., Singh, V. P. (2001): Evaluation and generalization of temperature-based methods for calculating evaporation. - Hydrol. Process. 15: 305-319.

[75] Zhang, Y. Q., Chiew, F. H. S., Zhang, L., Leuning, R., Cleugh, H. A. (2008): Estimating catchment evaporation and runoff using MODIS leaf area index and the Penman-Monteith equation. - Water Resour. Res. 44.

[76] Zhou, J., Wang, Y., Su, B., Wang, A., Tao, H., Zhai, J., Kundzewicz, Z. W., Jiang, T. (2020): Choice of potential evapotranspiration formulas influences drought assessment: A case study in China. - Atmos. Res. 242: 104979. 